\title{
Purines and Carotid Body: New Roles in Pathological Conditions
}

\author{
Silvia V. Conde*, Emilia C. Monteiro and Joana F. Sacramento
}

Centro de Estudos de Doenças Crónicas, NOVA Medical School - Faculdade de Ciências Médicas, Universidade NOVA de Lisboa, Lisboa, Portugal

\section{OPEN ACCESS}

Edited by:

Kenneth A. Jacobson, National Institutes of Health $(\mathrm{NIH})$, United States

Reviewed by:

Eric Boué-Grabot,

UMR5293 Institut des Maladies Neurodégénératives (IMN), France Ana Paula Abdala,

University of Bristol, United Kingdom

${ }^{*}$ Correspondence:

Silvia V. Conde

silvia.conde@nms.unl.pt

Specialty section:

This article was submitted to Experimental Pharmacology and Drug

Discovery,

a section of the journal

Frontiers in Pharmacology

Received: 17 October 2017 Accepted: 29 November 2017 Published: 12 December 2017

Citation:

Conde SV, Monteiro EC and Sacramento JF (2017) Purines and Carotid Body: New Roles

in Pathological Conditions.

Front. Pharmacol. 8:913. doi: 10.3389/fphar.2017.00913
It is known that adenosine and adenosine- $5^{\prime}$-triphosphate (ATP) are excitatory mediators involved in carotid body (CB) hypoxic signaling. The CBs are peripheral chemoreceptors classically defined by $\mathrm{O}_{2}, \mathrm{CO}_{2}$, and $\mathrm{pH}$ sensors. When hypoxia activates the $\mathrm{CB}$, it induces the release of neurotransmitters from chemoreceptor cells leading to an increase in the action potentials frequency at the carotid sinus nerve (CSN). This increase in the firing frequency of the CSN is integrated in the brainstem to induce cardiorespiratory compensatory responses. In the last decade several pathologies, as, hypertension, diabetes, obstructive sleep apnea and heart failure have been associated with $\mathrm{CB}$ overactivation. In the first section of the present manuscript we review in a concise manner fundamental aspects of purine metabolism. The second section is devoted to the role of purines on the hypoxic response of the $\mathrm{CB}$, providing the stateof-the art for the presence of adenosine and ATP receptors in the CB; for the role of purines at presynaptic level in CB chemoreceptor cells, as well as, its metabolism and regulation; at postsynaptic level in the CSN activity; and on the ventilatory responses to hypoxia. Recently, we have showed that adenosine is involved in CB hypersensitization during chronic intermittent hypoxia $(\mathrm{ClH})$, which mimics obstructive sleep apnea, since caffeine, a non-selective adenosine receptor antagonist that inhibits $A_{2 A}$ and $A_{2 B}$ adenosine receptors, decreased CSN chemosensory activity in animals subjected to $\mathrm{ClH}$. Apart from this involvement of adenosine in CB sensitization in sleep apnea, it was recently found that P2X3 ATP receptor in the CB contributes to increased chemoreflex hypersensitivity and hypertension in spontaneously hypertension rats. Therefore the last section of this manuscript is devoted to review the recent findings on the role of purines in CB-mediated pathologies as hypertension, diabetes and sleep apnea emphasizing the potential clinical importance of modulating purines levels and action to treat pathologies associated with $\mathrm{CB}$ dysfunction.

Keywords: carotid body, adenosine, ATP, hypertension, chronic intermittent hypoxia, type 2 diabetes

\section{PURINES METABOLISM}

From all purines, adenosine and adenosine- $5^{\prime}$-triphosphate (ATP) are the only ones that are known to have a role in cell to cell communication and therefore they act extracellularly to mediate several biological effects via cell-surface receptors, the purine receptors. ATP has a fundamental intracellular role as universal source of energy for all living cells. The demonstration of its release into the extracellular space and the identification and localisation of specific receptors on target cells have been essential in establishing its extracellular physiological role. In the beginning of 
the seventies, the purinergic neurotransmission was first proposed by Burnstock (1972). ATP was shown to be released from non-adrenergic, non-cholinergic nerves to signaling inhibitory enteric nerves in the guinea pig taenia coli and excitatory parasympathetic nerves in the urinary bladder (Burnstock et al., 1970, 1972). However, the concept of purinergic neurotransmission was only established in the nineties, when receptors for adenosine and ATP were cloned and sequenced (for a review see Ralevic and Burnstock, 1998). Short-term purinergic signaling was first described when ATP was identified as a cotransmitter with noradrenalin, acetylcholine and with substance $P$ and calcitonin gene-related peptide (for a review see Burnstock, 2016) in the peripheral nervous system. Later ATP was shown to be a cotransmitter in neurons in the central nervous system (CNS), being co-released with GABA (Jo and Schlichter, 1999; Jo and Role, 2002) and Glutamate (Pankratov et al., 1999). Adenosine is a product of ATP catabolism, which can be used to resynthesize ATP itself. This mediator is an ubiquitous substance that is not stored or released as a classical neurotransmitter, being released by almost all cell types through nucleoside transporters (Fredholm et al., 2001). Intracellularly it has key roles in pathways as purinergic nucleic acid base synthesis, amino acid metabolism and modulation of cellular metabolic status (Conde et al., 2009). Extracellularly, adenosine modulates the activity of several systems at presynaptic level (inhibiting or facilitating neurotransmitters release), at postsynaptic or at non-synaptic level (e.g., modulating blood flow or the metabolism of sustentacular cells).

\section{Metabolic Pathways of Adenosine Formation and Release}

Adenosine is mostly formed by the catabolism of $5^{\prime}$ adenosine phosphates (ATP, adenosine diphosphate - ADP and adenosine monophosphate - AMP). Intracellular adenosine production is mediated by an intracellular $5^{\prime}$-nucleotidase that dephosphorylates AMP (Schubert et al., 1979; Zimmermann et al., 1998) or by the hydrolysis of S-adenosylhomocysteine by $S$-adenosylhomocysteine hydrolase (Broch and Ueland, 1980) (Figure 1). Extracellular adenosine comes from ATP hydrolysis via 5'ectonucleotidases (Fredholm et al., 2001; Yegutkin, 2008) and by its intracellular production and release by nucleoside transport system (for a review see Conde et al., 2009). Another source of adenosine that is present extracellularly is cyclic AMP (cAMP) that can be released by secretory cells and converted by extracellular ectophosphodiesterases in AMP and then into adenosine by $5^{\prime}$-ectonucleotidases (Fredholm et al., 2001).

In contrast with other neurotransmitters, adenosine is not stored in synaptic vesicles or acts exclusively on synapses. Its release and uptake occurs through nucleoside transporters, which are constituted by two families: a $\mathrm{Na}^{+}$independent family and another one dependent of the same ion (Griffith and Jarvis, 1996). The $\mathrm{Na}^{+}$dependent-nucleoside transport system is concentrative, carrying nucleosides against a concentration gradient. The $\mathrm{Na}^{+}$independent-nucleoside transport system (equilibrative nucleoside transport system, ENT) is bi-directional and is formed by two different families (es and ei), classified based on their sensitivity to nitrobenzylthioinosine (NBTI). The es transport is inhibited by low nanomolar concentrations of NBTI, while ei transport requires micromolar concentrations to be inhibited (Griffith and Jarvis, 1996; Cass et al., 1998; Podgorska et al., 2005).

The major pathways of adenosine removal or degradation involve reactions catalyzed by two enzymes: adenosine kinase (AK) and adenosine deaminase (ADA) (Fredholm et al., 1999), which leads to the formation of inosine and AMP, respectively (Conde et al., 2009). ADA is mostly found in the intracellular space, however, it is also found in some extracellular compartments. This enzyme has relevance when adenosine concentrations are high (Arch and Newsholme, 1978) and alterations in its activity have been associated with several pathologies, such as miastenia gravis and diabetes mellitus (Hoshino et al., 1994; Oliveira et al., 2015).

\section{Adenosine Receptors}

Adenosine exerts is action through four different type of adenosine receptors coupled to $G$ proteins $A_{1}, A_{2} A, A_{2 B}$, and $A_{3}$ (Conde et al., 2009). These receptors are activated by different endogenous adenosine concentrations being the affinity for adenosine: $A_{1}>A_{2 A}>A_{2 B}>A_{3}$. The adenosine that is available endogenously to activate these receptors is in equilibrium with the density of adenosine receptors at the site of action to help to control the different physiological responses to this nucleotide (Conde et al., 2009).

$A_{1}$ and $A_{2}$ adenosine receptors have been subdivided based on their capacity of inhibiting and stimulating adenylyl cyclase and therefore, their ability to decrease and increase the cAMP levels, respectively. In fact, $A_{1}$ and $A_{2}$ adenosine receptors are $G_{i}$ and $G_{S}$-coupled receptors, respectively. The $A_{3}$ adenosine receptors are also coupled to $G_{i}$ proteins (Fredholm et al., 2001). However, nowadays there are some evidences that adenosine receptors may activate signaling pathways via other $G$ proteins, for example $A_{1}$ receptors are coupled preferentially to $G_{i 1 / 2 / 3}$, but they can also be coupled to $G_{0}$. On the other hand, although $\mathrm{A}_{2 \mathrm{~A}}$ and $\mathrm{A}_{2 \mathrm{~B}}$ receptors preferentially activate $G_{S}$ proteins, they can also activate $G_{\text {olf }}$ and $G_{15 / 16}$, and $\mathrm{G}_{\mathrm{q}}$, respectively (Fredholm et al., 2001). $A_{3}$ receptors that activate $\mathrm{G}_{\mathrm{i} / \mathrm{o}}$ proteins can also activate $\mathrm{G}_{\mathrm{q}}$ (Conde et al., 2009). Apart from the activation of enzymes, the activation of $\mathrm{G}$ coupled proteins acts on ion channels. In addition it has been shown in hippocampal slices that $A_{1}$ adenosine receptors activate $\mathrm{N}, \mathrm{P}$, and Q-type $\mathrm{Ca}^{2+}$ channels (Wu and Saggau, 1994), several types of $\mathrm{K}^{+}$channels in cultured striatum mouse neurons (Trussell and Jackson, 1985) and also lead to the activation of phospholipase C (Fredholm et al., 2001). $A_{3}$ receptors seem to mediate the same effectors than $A_{1}$ receptors. The main second messenger involved in the activation of $A_{2 A}$ and $A_{2 B}$ receptors is cAMP, with the stimulation of these receptors originating an increase in cAMP intracellular levels, however, other actions, including 


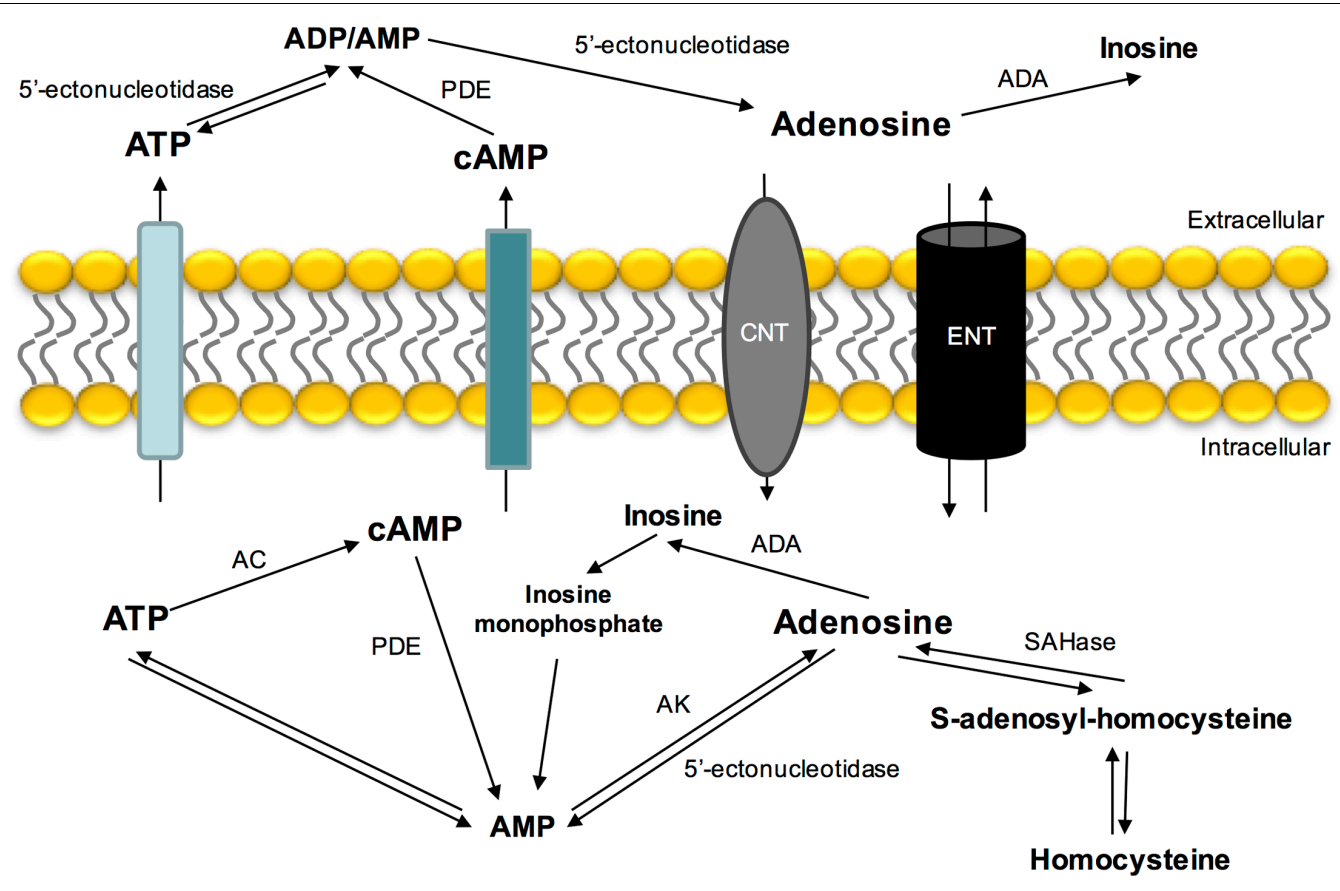

FIGURE 1 | Extra- and intracellular adenosine metabolism and nucleoside transporters that contribute to its release, uptake and production. ADA, adenosine deaminase; AC, adenylyl cyclase; AK, adenosine kinase; CNT, concentrative nucleoside transporter; ENT, equilibrative nucleoside transporter; PDE, phosphodiesterase; SAHase, S-adenosyl homocysteine hydrolase.

mobilization of intracellular calcium, have also been described (for a review see Fredholm et al., 2001).

\section{Metabolic Pathways of ATP Formation and Release}

Adenosine- $5^{\prime}$-triphosphate is released from several cells in physiological conditions and/or pathophysiologically in response to hypoxia, inflammation, to mechanical stress and to some antagonists (Bodin and Burnstock, 2001; Burnstock, 2016). Classically, ATP was known to be released from nerve terminals by exocytosis, via $\mathrm{Ca}^{2+}$ dependent mechanisms (Zimmermann, 2016). However, apart from being released from nerve terminals it can be also released by glial cells such as astrocytes (Gordon et al., 2005) through ATP-bindingcassette transporters, surface-located hemichannels (connexin, pannexin) and plasmalemmal voltage-dependent anion channels (Zimmermann, 2016). Neuronal and glial ATP modulate postsynaptic strength though activation of postsynaptic P2X receptors (Gordon et al., 2005; Khakh and North, 2012; Pougnet et al., 2014, Neuron).

After released and exerting its action on its receptors, ATP must be removed from the synaptic clef, which is mainly performed by its breakdown by diverse types of ectonucleotidases. There are four large families of ectonucleotidase enzymes: ectonucleotide pyrophosphatase/ phosphodiesterase (E-NPP), which hydrolyze ATP to AMP; ectonucleoside triphosphate diphosphohydrolase (E-NTDPase), which hydrolyze ATP to ADP or AMP; alkaline phosphatase which generate adenosine; and $5^{\prime}$-ectonucleotidase which hydrolyzed AMP to adenosine (Zimmermann et al., 2007; Knowles, 2011).

\section{ATP Receptors}

Adenosine- $5^{\prime}$-triphosphate exerts its physiological actions by the activation of its receptors that have been divided in two families: P2X ionotropic ligand-gated ion channel receptors and P2Y metabotropic G-protein-coupled receptors (Abbracchio and Burnstock, 1994; Fredholm et al., 1994). Currently are described seven subtypes of $\mathrm{P} 2 \mathrm{X}$ receptors $\left(\mathrm{P} 2 \mathrm{X}_{1}-\mathrm{P} 2 \mathrm{X}_{7}\right)$ (Fredholm et al., 1994; Ralevic and Burnstock, 1998) and eight subtypes of $P 2 Y$ receptors $\left(\mathrm{P}_{2} \mathrm{Y}_{1}, \mathrm{P}_{2} \mathrm{Y}_{2}, \mathrm{P}_{2} \mathrm{Y}_{4}, \mathrm{P}_{2} \mathrm{Y}_{6}, \mathrm{P}_{2} \mathrm{Y}_{11}, \mathrm{P} 2 \mathrm{Y}_{12}, \mathrm{P}_{2} \mathrm{Y}_{13}, \mathrm{P}_{2} \mathrm{Y}_{14}\right)$ (Burnstock and Knight, 2004).

The P2Y receptors are divided into two subgroups. $\mathrm{P} 2 \mathrm{Y}_{1}$, $\mathrm{P}_{2} \mathrm{Y}_{2}, \mathrm{P}_{2} \mathrm{Y}_{4}$, and $\mathrm{P} 2 \mathrm{Y}_{6}$ that activate $\mathrm{G}_{\mathrm{q}}$ coupled proteins and phospholipase $C \beta$, leading to the formation of inositol 1,4,5-trisphosphate (IP3) which increases intracellular $\mathrm{Ca}^{2+}$, and diacylglycerol which activates protein kinase C. In contrast, $\mathrm{P}_{2} \mathrm{Y}_{12}, \mathrm{P}_{2} \mathrm{Y}_{13}$, and $\mathrm{P}_{2} \mathrm{Y}_{14}$ activate $\mathrm{G}_{i}$, inhibiting adenylyl cyclase and decreasing intracellular cAMP levels. $\mathrm{P}_{2} \mathrm{Y}_{11}$ receptor activates both $\mathrm{Gq}$ and $\mathrm{Gs}$, which increases both intracellular $\mathrm{Ca}^{2+}$ and cAMP (Zimmermann, 2016). The seven P2X receptor subunits assemble to form trimeric homomers and often some combinations of trimeric heteromers (Lewis et al., 1995; Torres et al., 1999) that mediate rapid (within $10 \mathrm{~ms}$ ) and selective permeability to $\mathrm{Na}^{+}, \mathrm{K}^{+}$, and $\mathrm{Ca}^{2+}$ ions (Khakh and North, 2006). This is in accordance with their role as mediators of ATP action as neurotransmitter or neuromodulator of fast synaptic transmission (Khakh and North, 2012; Boué-Grabot 
and Pankratov, 2017) in both central and peripheral nervous systems. These $\mathrm{P} 2 \mathrm{X}$ receptors can be located at pre-synaptic level (facilitating neurotransmitter release) and at post-synaptic level modulating synapse strength (for a review see North, 2016). In contrast, P2Y receptors, which involves coupling to G proteins and second-messenger systems present a slower onset of response (less than $100 \mathrm{~ms}$ ) to ATP (for a review Ralevic and Burnstock, 1998).

\section{ROLE OF PURINES ON THE HYPOXIC RESPONSE IN THE CAROTID BODY}

\section{The Carotid Bodies}

The carotid bodies (CB) are paired chemoreceptors located in the bifurcation of the common carotid artery that are involved in the sensing of changes in arterial blood gasses such as hypoxia, hypercapnia, and acidosis. These stimuli generate action potentials at the $\mathrm{CB}$ sensitive nerve, the CSN, that are integrated in the brainstem to induce cardiorespiratory responses, to normalize blood gasses via hyperventilation (Gonzalez et al., 1994), and to regulate blood pressure and cardiac performance via activation of the sympathetic nervous system (Marshall, 1994).

The CB is organized into glomeruli, which are clusters of cells in close contact with a profuse network of capillaries and connective tissue. Each glomerulus contains chemoreceptor cells, also known as glomus or type I cells, which are derived of the neural crest and that are synaptically connected with the sensory nerve endings of the CSN (Gonzalez et al., 1994). Chemoreceptor cells contain several classical neurotransmitters as catecholamines (dopamine and norepinephrine), serotonin, acetylcholine, neuropeptides (substance $\mathrm{P}$ and enkephalins), but also contain ATP and adenosine (Gonzalez et al., 1994; Zhang et al., 2000; Rong et al., 2003; Buttigieg and Nurse, 2004; Conde and Monteiro, 2004; Conde et al., 2012a). Chemoreceptor/type I cells are enclosed by type II cells or sustentacular cells. It has been proposed that type II cells exhibit properties of stem cells that in response to hypoxia can proliferate and differentiate into new type I cells (Pardal et al., 2007).

\section{Adenosine and ATP Receptors in the Carotid Body}

The CB possesses receptors for both adenosine and ATP. The presence of $A_{1}$ receptors at the $C B$ is not consensual. Rocher et al. (1999) described that $A_{1}$ receptors are present in rabbit CB chemoreceptor cells, since $A_{1}$ antagonists, DPCPX $(10 \mu \mathrm{M})$ and 8-cyclopentyl-1,3-dimethylxantine $(0.1 \mu \mathrm{M})$ prevented the inhibitory action of adenosine on L-type $\mathrm{Ca}^{2+}$ currents and on the release of catecholamines. $A_{1}$ receptors were also detected in the whole rat CB structure (Bairam et al., 2009). However, other authors described that $A_{1}$ receptors are absent in rat CB chemoreceptor cells (Gauda et al., 2000; Kobayashi et al., 2000) being present in the petrosal ganglion neurons that also express tyrosine hydroxylase (TH) mRNA (Gauda, 2002). The discrepancies described between the existence of $A_{1}$ receptors in the $\mathrm{CB}$ could be due to different receptor localization in the $\mathrm{CB}$ structures and due to the different species studied.

Among the different adenosine receptor subtypes, $A_{2 A}$ and $A_{2 B}$ receptors were the main receptors localized in the $C B$ chemoreceptor cells. $A_{2 A}$ mRNA expression is developmentally regulated in the $\mathrm{CB}$ (Gauda et al., 2000) as it occurs with $\mathrm{TH}$ and dopamine $\mathrm{D}_{2}$-receptors mRNAs (Gauda et al., 1996). The expression of $\mathrm{A}_{2 \mathrm{~A}}$ receptors and their colocalization with $\mathrm{TH}$ in rat $\mathrm{CB}$ chemoreceptor cells have been demonstrated by immunocytochemistry (Gauda et al., 2000; Kobayashi et al., 2000). $A_{2 B}$ receptors were also present in rat CB chemoreceptor cells (Conde et al., 2006), as they colocalize with TH. Moreover, it was demonstrated, through the pharmacological decomposition of the effects of caffeine, a non-selective antagonist of adenosine receptors, on the CSN action potential frequency of discharge, that $\mathrm{A}_{2 \mathrm{~A}}$ are also present post-synaptically on the CSN (Conde et al., 2006).

The expression of $\mathrm{A}_{3}$ adenosine receptors was not detected in CB chemoreceptor cells (Kobayashi et al., 2000).

Regarding ATP receptors, McQueen and Ribeiro (1983) proposed for the first time the presence of $\mathrm{P} 2$ receptors in the cat $\mathrm{CB}$ based on experimental data obtained using the ATP analog, the $\alpha \beta$-methylene ATP. Later, the same authors concluded that $\mathrm{P} 2 \mathrm{X}$ receptors were present in the rat $\mathrm{CB}$, since P2X agonists activated the carotid chemoreceptor afferents (McQueen et al., 1998). In co-cultures of rat type I cells and petrosal ganglion cells $\mathrm{P} 2 \mathrm{X}_{2}$ receptors were present in the afferent terminals surrounding clusters of chemoreceptor cells, but not in chemoreceptor cells themselves, suggesting a post-synaptic localization (Zhang et al., 2000). One year later, a study from the same group showed that $\mathrm{P}_{2} \mathrm{X}_{3}$ receptors were also present in chemoafferent $\mathrm{CB}$ neurons and that $\mathrm{P} 2 \mathrm{X}_{2}$ and $\mathrm{P} 2 \mathrm{X}_{3}$ colocalize in synaptic terminals opposed to chemoreceptors cells, forming a heterodimeric receptor (Prasad et al., 2001). In addition, in co-cultures of rat $\mathrm{CB}$ and glossopharyngeal neurons it has also been showed that glossopharyngeal neurons expressed at least four different subtypes of $\mathrm{P} 2 \mathrm{X}$ receptors $\left(\mathrm{P} 2 \mathrm{X}_{2}, \mathrm{P}_{2} \mathrm{X}_{3}, \mathrm{P} 2 \mathrm{X}_{4}\right.$, and $\mathrm{P}_{2} \mathrm{X}_{7}$ ) (Campanucci et al., 2006).

Apart from the presence of $\mathrm{P} 2 \mathrm{X}$ ATP receptors, $\mathrm{P} 2 \mathrm{Y}$ receptors were also described in the CB (Xu et al., 2003, 2005). In rat CB dissociated cells it has been shown that ATP triggers a transient rise in intracellular $\mathrm{Ca}^{2+}$ in type II cells, but not in type I cells, and that $\mathrm{P}_{2} \mathrm{Y}_{2}$ receptors are localized in type II cells (Xu et al., 2003). Moreover, Xu et al. (2005) described the presence of $\mathrm{P}_{2} \mathrm{Y}_{1}$ receptors in the $\mathrm{CB}$ since it was observed in $\mathrm{CB}$ type I dissociated cells that ATP suppressed the hypoxia-induced intracellular $\mathrm{Ca}^{2+}$ rise via the activation of $\mathrm{P}_{2} \mathrm{Y}_{1}$ receptors being the order of purinoreceptor agonist potency in inhibiting the hypoxia response in agreement with the involvement of $\mathrm{P}_{2} \mathrm{Y}_{1}$ receptors.

\section{Adenosine Effects on Ventilation and on Carotid Sinus Nerve Activity}

Adenosine increases ventilation in several species, and this effect was attributed to the activation of $\mathrm{CB}$ chemoreceptors. Studies performed in humans showed that adenosine increases 
ventilation in a dose-dependent manner, an effect that is also dependent on the proximity of adenosine administration to the CB (Watt and Routledge, 1985; Watt et al., 1987), meaning that the effect is as higher as closer is adenosine administration from the CB. Consistent with the effect of adenosine in modulating ventilation via $\mathrm{CB}$ chemoreceptors, intra-arterially administration of adenosine in $\mathrm{dog}$ and cats showed that adenosine does not cross the blood brain barrier (Berne et al., 1974). Moreover, the effect of adenosine and its antagonists on ventilation in response to hypoxia was suggested to involve a mechanism of peripheral chemoreception, the $\mathrm{CB}$, rather than effects on CNS (Maxwell et al., 1986, 1987). In humans, the intravenous infusion of adenosine, that is commercially available as antiarrhythmic, induces chest discomfort, hyperventilation and dyspnea, being these effects attributed to CB chemoreceptors activation (Watt and Routledge, 1985; Maxwell et al., 1986, 1987; Watt et al., 1987; Uematsu et al., 2000).

In the rat, intracarotid administration of adenosine and its analogs increased in a dose-dependent manner ventilation an effect abolished after CSN section (Monteiro and Ribeiro, 1987). This excitatory effect of adenosine on ventilation was mediated by $\mathrm{A}_{2}$ receptors (Monteiro and Ribeiro, 1987; Ribeiro and Monteiro, 1991), and it seems that $A_{2 A}$ are responsible, at least in part, by this effect, since CGS21680, an $\mathrm{A}_{2 \mathrm{~A}}$ selective agonist, increased ventilation in rats by $31 \%$ (Conde et al., 2009). A work performed in rhesus monkeys also supports the excitatory effect of adenosine on ventilation (Howell and Landrum, 1995). In this work, it was described that caffeine, a non-selective adenosine receptor antagonist, attenuated hypoxia-induced increases in ventilation when animals were exposed to $10 \% \mathrm{O}_{2}$ (Howell and Landrum, 1995). Furthermore, intracarotid administration of erythro-9-(2hydroxy-3-nonyl) adenine (EHNA) and dipyridamole, inhibitors of adenosine deamination and uptake, respectively, leading to an increase in endogenous adenosine, emulated the excitatory effect of exogenous adenosine on ventilation (Monteiro and Ribeiro, 1989).

Besides, the demonstration of the role of adenosine on modulating ventilation via the $\mathrm{CB}$, in McQueen and Ribeiro (1981) described for the first time that adenosine can stimulate the CSN chemosensory activity. This effect of adenosine on CSN chemosensory activity was mimicked by adenosine analogs and inhibited by theophylline and 8-phenyltheophylline, suggesting the presence and involvement of $\mathrm{A}_{2}$ receptors (McQueen and Ribeiro, 1983, 1986). In vitro experiments in cats and rats corroborate these findings, since it was demonstrated that adenosine augments chemoreceptor discharge (Runold et al., 1990; Vandier et al., 1999), an effect that is dose dependent (Runold et al., 1990). Furthermore, McQueen and Ribeiro (1986) also described that intracarotid administration of 8-phenyltheophylline, an adenosine receptor antagonist, in the cat reduced the $\mathrm{CB}$ chemoreceptor response to hypoxia $(10 \%$ $\mathrm{O}_{2}$ ), which could indicate that adenosine released by the $\mathrm{CB}$ during hypoxia acts directly on nerve endings or as a modulator. These findings were supported by a previous work from the same group, where it was described an increase in CB chemoreceptor discharge in cat under normoxic conditions when adenosine uptake is inhibited by dipyridamole, suggesting that increases in the levels of endogenous adenosine cause chemoexcitation (McQueen and Ribeiro, 1983). In 2006, our group described that the CSN chemosensory activity elicited by hypoxia $\left(5 \% \mathrm{O}_{2}\right)$ is modulated by adenosine, an effect that is mediated by its action on both $\mathrm{A}_{2 \mathrm{~B}}$ presynaptic receptors (25\%) present in CB type I cells and $\mathrm{A}_{2 \mathrm{~A}}$ postsynaptic receptors (30\%) in CSN nerve endings (Conde et al., 2006).

\section{Effects of ATP on Ventilation and Carotid Sinus Nerve Activity}

The first evidence that ATP could affect ventilation was described by Anichkov and Belen'kii (1963), in a work that showed an increase in ventilation when ATP was administrated into the carotid bifurcation of decerebrated cats. Later, an autoradiographic study described the presence of ATP in the mouse CB (Kobayashi, 1976) and, nucleoside triphosphatase activity was detected in cat CB homogenates (Starlinger, 1982). Reyes et al. (2007) demonstrated in cats a dose-dependent excitatory effect of ATP on ventilation that was mediated through $\mathrm{P} 2$ receptors since the effect of $\mathrm{ATP}$ on ventilation was suppressed by suramin. Also, ATP and $\mathrm{P}_{2} \mathrm{X}_{2}$ receptors are involved in the ventilatory responses to hypoxia mediated by the $\mathrm{CB}$, since mice deficient in $\mathrm{P}_{2} \mathrm{X}_{2}$ receptors exhibited a prominent diminished ventilatory response to hypoxia, being this effect inversely correlated with hypoxia intensity, meaning that the decrease in ventilation is higher when the $\mathrm{PaO}_{2}$ decreases (Rong et al., 2003). In contrast, mice deficient in $\mathrm{P}_{2} \mathrm{X}_{3}$ receptors subunit showed a response to hypoxia comparable with the response of wild-type animals (Rong et al., 2003), suggesting that the $\mathrm{P}_{2} \mathrm{X}_{3}$ receptors that are also present in the $\mathrm{CB}$ do not mediate the ventilatory responses to hypoxia.

The results of ATP on ventilation are also consistent with the effect of ATP on CSN chemosensory activity. In the early 1950s, Jarisch et al. (1952) described an increase in CSN chemoreceptor discharge following an intracarotid administration of ATP. This excitatory effect of ATP on CSN chemoreceptor activity was also described by other in vivo and in vitro studies (Dontas, 1955; McQueen and Ribeiro, 1983; Ribeiro and McQueen, 1984; Spergel and Lahiri, 1993). Moreover, it was showed that this effect of ATP on CSN activity was dose-dependent (McQueen and Ribeiro, 1983; Alcayaga et al., 2000; Reyes et al., 2007; Soto et al., 2010) and due to ATP itself and not to its degradation into adenosine since the ATP agonists, $\beta \gamma$-methylene ATP promoted increases in the CSN chemoreceptor activity in cats (McQueen and Ribeiro, 1983; Reyes et al., 2007) and $\alpha \beta$-methylene ATP increased CSN discharges in rats (McQueen et al., 1998) and mice (Rong et al., 2003). Additionally, P2X receptor agonists induced rapid cardiorespiratory reflexes in anesthetized rat, suggesting the presence of this receptors in the rat $\mathrm{CB}$ (McQueen et al., 1998). These findings were supported by a work by Colin Nurse group (Zhang et al., 2000). They showed in a co-culture model of rat type I cell clusters and petrosal neurons that the application of suramin partially inhibited hypoxia-induced postsynaptic responses recorded in petrosal neurons (Zhang et al., 2000). In addition, both $\mathrm{P} 2 \mathrm{X}_{2}$ and $\mathrm{P} 2 \mathrm{X}_{3}$ receptor subunits were immunolocalized with petrosal afferent terminals in the rat 
CB (Zhang et al., 2000; Prasad et al., 2001). Furthermore, Rong et al. (2003) not only showed that $\mathrm{P}_{2} \mathrm{X}_{2}$ subunit are involved in the CB-mediated ventilatory responses to hypoxia, as herein described, but also showed a substantial decrease in the CSN responses to hypoxia in an in vitro CB-CSN preparation from mice deficient in $\mathrm{P}_{2} \mathrm{X}_{2}$ subunits. Therefore, is now accepted that ATP is an excitatory neurotransmitter at the synapse between the $\mathrm{CB}$ and the CSN and that is involved in the $\mathrm{CB}$ response to hypoxia. However, the contribution of ATP for the hypoxic signaling in the CB is dependent on hypoxia intensity, with ATP having a more pronounced role in the response to high intensity hypoxias and adenosine with moderate hypoxias (Conde et al., 2012a), suggesting that the response to hypoxia in the $C B$ are related with alterations in the ATP/adenosine metabolism.

While the effect of ATP in CB response to hypoxia is consensual, some controversy exists on the effect of ATP in fixing basal CSN activity. Zhang et al. (2000) described that suramin inhibited CSN basal activity. In contrast, our group reported that suramin did not modify CSN basal activity, which suggests that ATP is not the mediator involved in fixing the steady basal CSN chemosensory activity in adult rat (Conde et al., 2012a). These discrepancies could be related with developmental differences since the experiments performed by Zhang et al. (2000) were performed in postnatal 7- to 14-day-old rat pups. In fact, Niane et al. (2011) described a decrease in spontaneous CSN activity (80\%) in newborn rats, an effect was constant across ages (4- to 21-day-old rats). However, previous studies of the same authors (Donnelly and Doyle, 1994) have shown that both basal and hypoxia-induced CSN activity increases with age. Additionally, Niane et al. (2011) showed by the use of a specific $\mathrm{P}_{2} \mathrm{X}_{3}$ antagonist, A-317491, that in the $\mathrm{CB}$ from newborn rats, the $\mathrm{P} 2 \mathrm{X}_{3}$ receptor subunit plays a major role in the regulation of breathing under basal and hypoxic conditions, which is in contradiction with the results from Rong et al. (2003) in the mice. However, in both Zhang et al. (2000) and Niane et al. (2011) suramin was insufficient to fully promote inhibition of ventilation and the CSN chemosensory response to hypoxia suggesting that other excitatory co-transmitters are also involved (Fitzgerald, 2000; Iturriaga and Alcayaga, 2004; Zapata, 2007; Nurse, 2010; Conde et al., 2012a). Several authors have proposed the co-release of ATP-Acetylcholine, since the application of a mixture of nicotinic and purinergic antagonists completely suppress the CSN response to hypoxia (Zhang et al., 2000; Varas et al., 2003), however, Reyes et al. (2007) described that the perfusion of $\mathrm{CB}$ excised from cats with a mixture of nicotinic and purinergic antagonists was not able to eliminate the chemosensory response to hypoxia stimulation. Therefore, the hypothesis of the co-signaling of ATP-Acetylcholine in the $\mathrm{CB}$ remains controversial while the hypothesis of ATP-adenosine co-transmission gained many supporters.

\section{ATP and Adenosine Release from Carotid Body}

The first evidence for CB ATP release was a report describing a decrease in ATP content in the cat $\mathrm{CB}$ incubated with moderate hypoxia during $5 \mathrm{~min}$ or with cyanide, an inhibitor of the mitochondrial electron transport that induced a decrease in ATP and an increase in AMP content (Obeso et al., 1985, 1989). Also, rabbit CBs superfused during 15 min with cyanide or antimycin exhibit reduced ATP levels (Verna et al., 1990). In contrast with these results, it was observed that CB ATP levels were unchanged: (1) in cats exposed to hypoxia or hypercapnia (Acker and Starlinger, 1984); (2) in cat CBs incubated in the presence of dinitrophenol (Obeso et al., 1989), an uncoupler of oxidative phosphorylation that targets the mitochondria; (3) and in rabbit CBs superfused during 4-30 min with $10 \% \quad \mathrm{O}_{2}$-equilibrated Krebs-Henseleit solution (Verna et al., 1990). Buttigieg and Nurse (2004), described that acute hypoxia evoked an increase in extracellular ATP in the whole CB, an effect that was inhibited by L-type $\mathrm{Ca}^{2+}$ channel blockers. In addition, observations from our group showed that adult rat CBs incubated in Tyrode solution equilibrated with different $\mathrm{O}_{2}$ concentrations released higher concentrations of ATP when exposed to hypoxia $\left(2 \% \mathrm{O}_{2}\right.$ and $10 \% \mathrm{O}_{2}$ ) than when exposed to $20 \% \mathrm{O}_{2}$ and $95 \% \mathrm{O}_{2}$ (Conde and Monteiro, 2006). More recently, we showed that the release of ATP from rat CB is proportional with hypoxia intensity (Conde et al., 2012a) and that the increase in ATP release induced by hypoxia was completely prevented by removal of extracellular calcium and by a calcium chelating agent, suggesting that ATP released during hypoxia comes from a vesicular source through exocytosis (Conde and Monteiro, 2006; Conde et al., 2012a). Therefore, the signaling cascade between hypoxic signal and the release of ATP would be: (1) detection of hypoxia by an $\mathrm{O}_{2}$ sensor (molecular identity unknown), (2) closure of $\mathrm{K}^{+}$channels, (3) opening of $\mathrm{Ca}^{2+}$ channels, (4) increase in intracellular calcium, (5) release of ATP by exocytosis (Gonzalez et al., 1994, 2010; Conde et al., 2012a).

Adenosine is also released from the CB. Our group showed that in adult rat $\mathrm{CB}$ adenosine is released in normoxic conditions, and its release augments in response to 10 and $30 \mathrm{~min}$ of moderate hypoxia $\left(10 \% \mathrm{O}_{2}\right)$ (Conde and Monteiro, 2004), but is not modified by hyperoxic exposure $\left(95 \% \mathrm{O}_{2}\right)$ (Conde and Monteiro, 2006). These experiments were performed under incubation of adenosine deaminase due to the short life-time of adenosine and to avoid its degradation. In contrast, the $\mathrm{CB}$ adenosine content was drastically reduced after $30 \mathrm{~min}$ of hypoxic exposure (Conde and Monteiro, 2004). Also, we have showed that approximately $40 \%$ of adenosine present extracellularly in the CB came from extracellular ATP degradation, both under normoxic and hypoxic conditions and that low $\mathrm{pO}(2)$ triggers adenosine efflux through the activation of NBTI-sensitive ENT. This effect was only apparent in hypoxia and when adenosine extracellular concentrations were reduced by the blockade of ecto- $5^{\prime}$-nucleotidase (Conde and Monteiro, 2004).

Although we have showed that both ATP extracellular catabolism as well as release of adenosine per se through an NBTI-sensible ENT can account to the amount of adenosine present in the CB-CSN synapse, we cannot exclude another sources of extracellular adenosine, as cAMP. Even though several studies reported the role of cAMP in CB chemotransduction and/or chemotransmission (Nunes et al., 2014), the contribution of extracellular CAMP to extracellular adenosine has never been investigated in the CB. Additionally, other mechanisms, such as 
inhibition of $S$-adenosylhomocysteine and adenosine deaminase, could be involved in adenosine production and release by the $\mathrm{CB}$ in normoxia and hypoxia.

Additionally, our group demonstrated that adenosine is preferentially released in response to moderate hypoxia $\left(10 \% \mathrm{O}_{2}\right)$ than in response to higher hypoxic intensities $\left(2 \% \mathrm{O}_{2}\right.$ and $5 \%$ $\mathrm{O}_{2}$ ), while $\mathrm{CB}$ ATP release had a more pronounced role during high intensity hypoxias (Conde et al., 2012a). These findings were corroborated by electrophysiological data showing that ZM241385, in a concentration that block $\mathrm{A}_{2}$ adenosine receptors $\left(\mathrm{A}_{2 \mathrm{~A}}\right.$ and $\left.\mathrm{A}_{2 \mathrm{~B}}, 300 \mathrm{nM}\right)$, inhibits CSN chemosensory activity with higher efficacy in moderate hypoxia than in intense hypoxia (Conde et al., 2012a). Furthermore, it was also shown that during a high-intense hypoxia the main origin of extracellular adenosine is ATP catabolism, whereas at moderate hypoxia the main source of adenosine is its release per se by the ENT (Conde et al., 2012a). All together these findings showed that adenosine acting on the $\mathrm{CB}$ via $\mathrm{A}_{2 \mathrm{~A}}$ and $\mathrm{A}_{2 \mathrm{~B}}$ receptors together with ATP acting on $\mathrm{P} 2 \mathrm{X}$ receptors are key neurotransmitters involved in hypoxic $\mathrm{CB}$ chemotransduction, depending the contribution of each neurotransmitter on the hypoxia intensity.

As previously described, the conversion of ATP to adenosine requires both membrane bound E-NTDPase and 5 -ectonucleotidases and, it was recently described that E-NTDPase2,3 are expressed prominently in the periphery of $\mathrm{CB}$ type I cells in the vicinity with CSN endings and that 5 -ectonucleotidase (CD73) is expressed in both types I and II cells (Salman et al., 2017). Holmes et al. (2017) recently showed that the inhibition of CD73 decreased the basal CSN activity and attenuated the responses to hypoxia. These authors also described that the in vivo inhibition of CD73 with AOPCP, blunted the hypoxic ventilatory response and reduced the elevation in the heart rate induced by hypoxia, showing that CD73 regulates peripheral chemoreceptor activity and the cardiorespiratory responses to hypoxia (Holmes et al., 2017). Additionally, it has been shown that under chronic hypobaric hypoxia an upregulation of E-NTDPase3 and CD73 was observed, while E-NTDPase2 was downregulated, suggesting that this differential regulation leading to alterations in purinergic adenosine and $\mathrm{P} 2$ receptors signaling, may contribute to $\mathrm{CB}$ plasticity during chronic hypoxia (Salman et al., 2017). These results together suggest a hypoxic modulation of purines metabolism at the $\mathrm{CB}$ that control the contribution of adenosine and ATP in $\mathrm{CB}$ chemotransduction both in basal conditions as well as in the responses to acute and chronic hypoxia.

\section{Cellular Actions of Adenosine in the Carotid Body}

At the moment, it is accepted that the chemoexcitatory effect of adenosine at the $\mathrm{CB}$ involves the activation of adenosine receptors and consequently the activation of cellular pathways activated by G-coupled receptors as well as alterations in cAMP and $\mathrm{Ca}^{2+}$ intracellular levels, cell depolarization among other events. There is a consensus that adenosine and its analogs increase cAMP levels in the rat (Monteiro et al., 1996; Conde et al., 2008) and rabbit CB (Chen et al., 1997). Hypoxia also induced an increase in cAMP in CB type I cells (Pérez-García et al., 1990; Wang et al., 1991) an effect that was potentiated by adenosine, since dipyridamole, an inhibitor of adenosine uptake, increased cAMP content in rabbit $\mathrm{CB}$ superfused with $5 \% \mathrm{O}_{2}$. This effect was blocked by $\mathrm{A}_{2}$ adenosine receptors antagonists (Chen et al., 1997) meaning that $A_{2}$ receptors mediated the increase in CAMP produced by hypoxia. More recently, it was shown that this increase in CAMP levels evoked by adenosine is mostly mediated by the activation of $\mathrm{A}_{2 \mathrm{~B}}$ adenosine receptors (Conde et al., 2008).

Another effector of cAMP is $\mathrm{K}^{+}$channels, and in fact $\mathrm{K}^{+}$ channels are known to be modulated by the increase in cAMP levels induced by adenosine at the CB (López-López et al., 1993). López-López et al. (1993) showed that the application of a cAMP analog, dibutyryl cAMP, in isolated rabbit type I cells, decreased the amplitude of 4-aminopyridine-sensitive $\mathrm{K}^{+}$ currents, an effect that is voltage independent. In contrast, Hatton and Peers (1996) demonstrated that dibutyryl cAMP (5 mM) and 8-bromo-cAMP ( $2 \mathrm{mM}$ ) were unable to modify $\mathrm{K}^{+}$current amplitudes in isolated rat type I cells. These discrepant results could be related with animal's age and with differences between the electrophysiological properties and responses to hypoxia of rabbit and rat type I cells (Peers and Buckler, 1995). Furthermore, Vandier et al. (1999) showed that adenosine decreased the amplitude of 4-aminopyridine-sensitive $\mathrm{K}^{+}$currents in isolated rat type I cells, an effect that is voltage independent and mainly $\mathrm{Ca}^{2+}$ dependent. However, a small but significant component of the current blocked by adenosine was $\mathrm{Ca}^{2+}$ dependent (Vandier et al., 1999). Additionally, in isolated rabbit type I cells, adenosine inhibits L-type $\mathrm{Ca}^{2+}$ channels and the release of catecholamines induced by hypoxia, an effect that was described to be mediated by $A_{1}$ adenosine receptors, since $A_{1}$ agonists and antagonists are capable of modulate $\mathrm{Ca}^{2+}$ currents (Rocher et al., 1999). Kobayashi et al. (2000) also described that adenosine inhibits voltage-dependent $\mathrm{Ca}^{2+}$ currents in isolated rat type I cells. However, this effect was attributed to $\mathrm{A}_{2 \mathrm{~A}}$ adenosine receptors, since ZM241385, in a concentration that is specific for $A_{2 A}$ receptors $(10 \mathrm{nM})$, abolished the effect of adenosine on $\mathrm{Ca}^{2+}$ currents (Kobayashi et al., 2000). This discrepancies as previously discussed could be attributed to differences between species. Additionally, adenosine attenuated the increase in intracellular $\mathrm{Ca}^{2+}$ evoked by hypoxia without changing the intracellular $\mathrm{Ca}^{2+}$ in cells exposed to normoxia (Kobayashi et al., 2000). In contrast, $\mathrm{Xu}$ et al. (2006) observed that adenosine via $\mathrm{A}_{2 \mathrm{~A}}$ receptors elicited a rise in intracellular $\mathrm{Ca}^{2+}$. The authors also described that this effect of adenosine on intracellular $\mathrm{Ca}^{2+}$ occurs through the action of adenosine on adenylate cyclase and protein kinase $\mathrm{A}$ pathways, which inhibits the TWIK-related acid-sensitive $\mathrm{K}^{+}-1$ (TASK-1) channels, leading to depolarization and, therefore to $\mathrm{Ca}^{2+}$ entry via voltage-gated $\mathrm{Ca}^{2+}$ channels (VGCC) (Xu et al., 2006; Tse et al., 2012). However, the increase in the intracellular $\mathrm{Ca}^{2+}$ observed by Xu et al. (2006) may be insufficient to evoke the release of neurotransmitters, since it is much smaller than the increase that evokes the release of catecholamines from the rat $\mathrm{CB}$ (Vicario et al., 2000). Moreover, the block of $\mathrm{A}_{2 \mathrm{~A}}$ adenosine receptors with $\mathrm{SCH} 58261$, a selective antagonist of $\mathrm{A}_{2 \mathrm{~A}}$ receptors in the concentration used $(5 \mathrm{nM})$, decreases hypoxia-evoked 


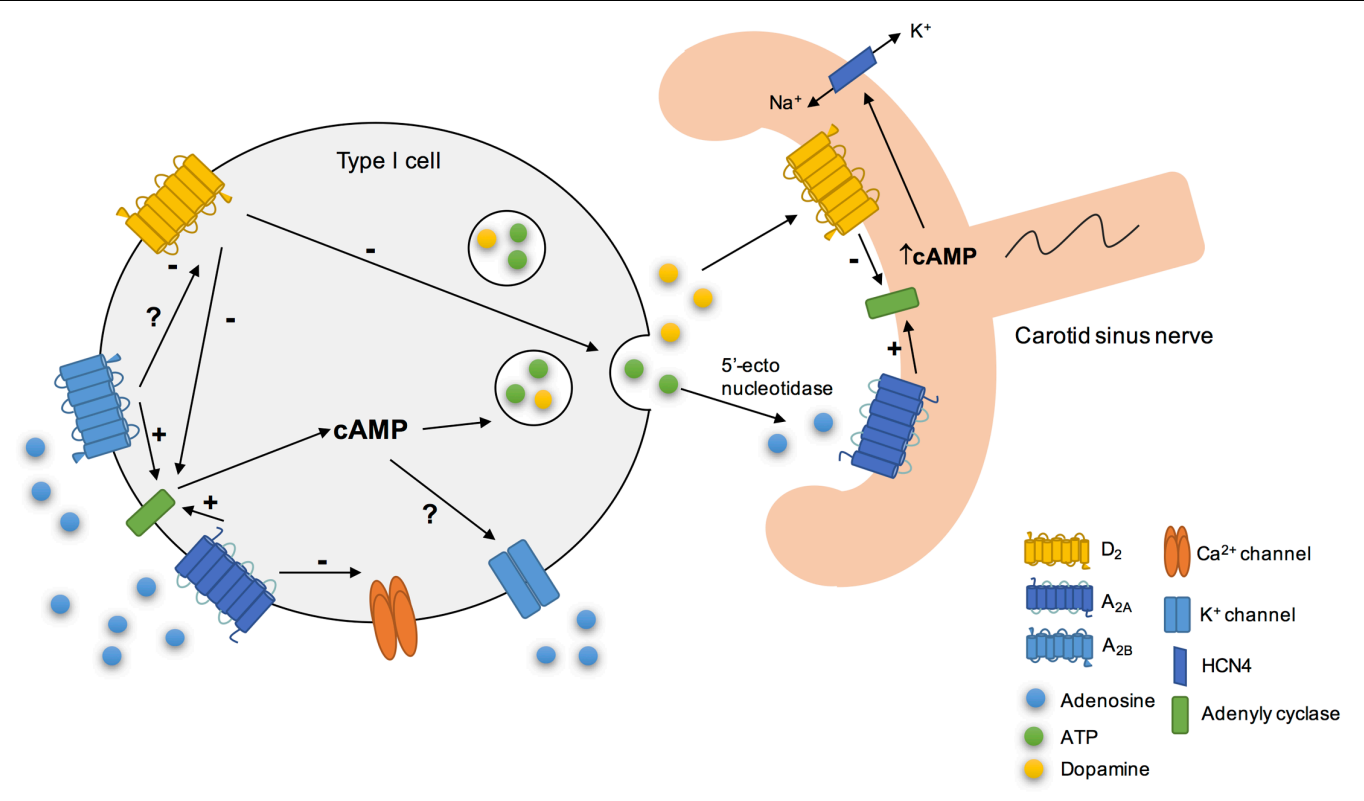

FIGURE 2 | Schematic representation of some of adenosine cellular actions on rat carotid body (CB). Adenosine increased cAMP content in type I cells via $\mathrm{A}_{2 \mathrm{~A}}$ and $\mathrm{A}_{2 \mathrm{~B}}$ action on adenylyl cyclase, leading to the release of neurotransmitters, as catecholamines (Conde et al., 2008). Additionally, its action on these receptors could modulate $\mathrm{K}^{+}$currents (López-López et al., 1993) for example by decreasing the amplitude of $\mathrm{K}^{+}$currents (Vandier et al., 1999) and inhibit the voltage-dependent $\mathrm{Ca}^{2+}$ currents in type I cells. During hypoxia, adenosine released per se through the equilibrative nucleoside transport system or generated by the extracellular breakdown of ATP by 5'-ectonucleotidases (Conde and Monteiro, 2004; Conde et al., 2012a; Salman et al., 2017), acts postsynaptically on A 2 A receptors, leading to adenylyl cyclase activation and to an increase in cAMP, which stimulates HCN4-containing non-selective cation channels that mediate $/ \mathrm{h}$, leading to an increase in membrane excitability. In contrast, dopamine exerts the opposite effect, leading to a decrease in petrosal membrane excitability (Zhang et al., 2017).

receptor potentials in rat type I cells (Nurse and Piskuric, 2013). The role of adenosine in modulating CB cells function in chronic hypoxia was also highlighted by the fact that the exposure of rat $\mathrm{CB}$ cultures to chronic hypoxia $\left(2 \% \mathrm{O}_{2}, 24 \mathrm{~h}\right)$ induced an augment in adenosine-evoked increases intracellular $\mathrm{Ca}^{2+}$ transients and catecholamine secretion from CB type I cells, an effect that is mediated by $A_{2 B}$ receptors (Livermore and Nurse, 2013). This pathway could contribute to $C B$ sensitization during ventilatory acclimatization to hypoxia in animals and humans exposed to chronic hypoxia in vivo (Conde et al., 2009; Teppema and Dahan, 2010).

Adenosine also acts as a neuromodulator in $\mathrm{CB}$ chemoreceptor cells since it acts to modulate the release of other neurotransmitters. It has been showed that adenosine is involved in the release of catecholamines through the antagonist interaction between $\mathrm{A}_{2 \mathrm{~B}}$ and dopamine $\mathrm{D}_{2}$ receptors (Conde et al., 2008) (Figure 2). This interaction between $A_{2 B}$ and $D_{2}$ receptors in $\mathrm{CB}$ chemoreceptors cells is evident at adenylyl cyclase level, since $\mathrm{D}_{2}$ agonists inhibited cAMP production in $\mathrm{CB}$, an effect that is prevented by an $\mathrm{A}_{2 \mathrm{~B}}$ receptor antagonist and occurs in basal conditions as well as hypoxia (Conde et al., 2008). However, an antagonistic interaction at the $A_{2 B}-D_{2}$ receptor level, similar to that described in the CNS for $\mathrm{A}_{2 \mathrm{~A}^{-}}$ $\mathrm{D}_{2}$ receptors (Fuxe et al., 2007) cannot be excluded. These results are in agreement with a previous work from Monteiro and Ribeiro (2000) that described an enhancement of the inhibitory effect of dopamine on ventilation induced by the intracarotid infusion of adenosine. Regarding the interactions between adenosine and dopamine at postsynaptic level, a recent work from Zhang et al. (2017) showed in co-culture of rat CB type I cells and sensory petrosal neurons that adenosine increases a hyperpolarization-activated cyclic nucleotidegated $(\mathrm{HCN})$ cation current $I_{\mathrm{h}}$ in chemosensory petrosal neurons through $A_{2 A}$ receptors, whereas dopamine had the opposite effect through $\mathrm{D}_{2}$ receptors. The effect of adenosine on $\mathrm{HCN}$ cation current $I_{\mathrm{h}}$ seems to involve the activation of adenylyl cyclase and the increase in intracellular cAMP that in turn activates HCN4-containing non-selective cation channels that mediate $I_{\mathrm{h}}$ (Zhang et al., 2017). Moreover, the authors obtained evidence for a presynaptic role for adenosine acting via $\mathrm{A}_{2 \mathrm{~A}}$ receptors during chemotransduction, since SCH58261 inhibited both hypoxia-induced presynaptic receptor potential and postsynaptic petrosal response (Zhang et al., 2017).

\section{Cellular Actions of ATP in the Carotid Body}

During hypoxia it was observed that rat chemoreceptors cells depolarized due to the closure of TASK1/3 background $\mathrm{K}^{+}$ channels (Buckler, 2015) leading to the activation of extracellular $\mathrm{Ca}^{2+}$ entry via VGCCs triggering the release of several neurotransmitters from chemoreceptor cells, including ATP and adenosine (Buttigieg and Nurse, 2004; Conde and Monteiro, 2004; Conde et al., 2012a). In addition, it has been shown that ATP released by type I cells can induce a rise in intracellular $\mathrm{Ca}^{2+}$ 


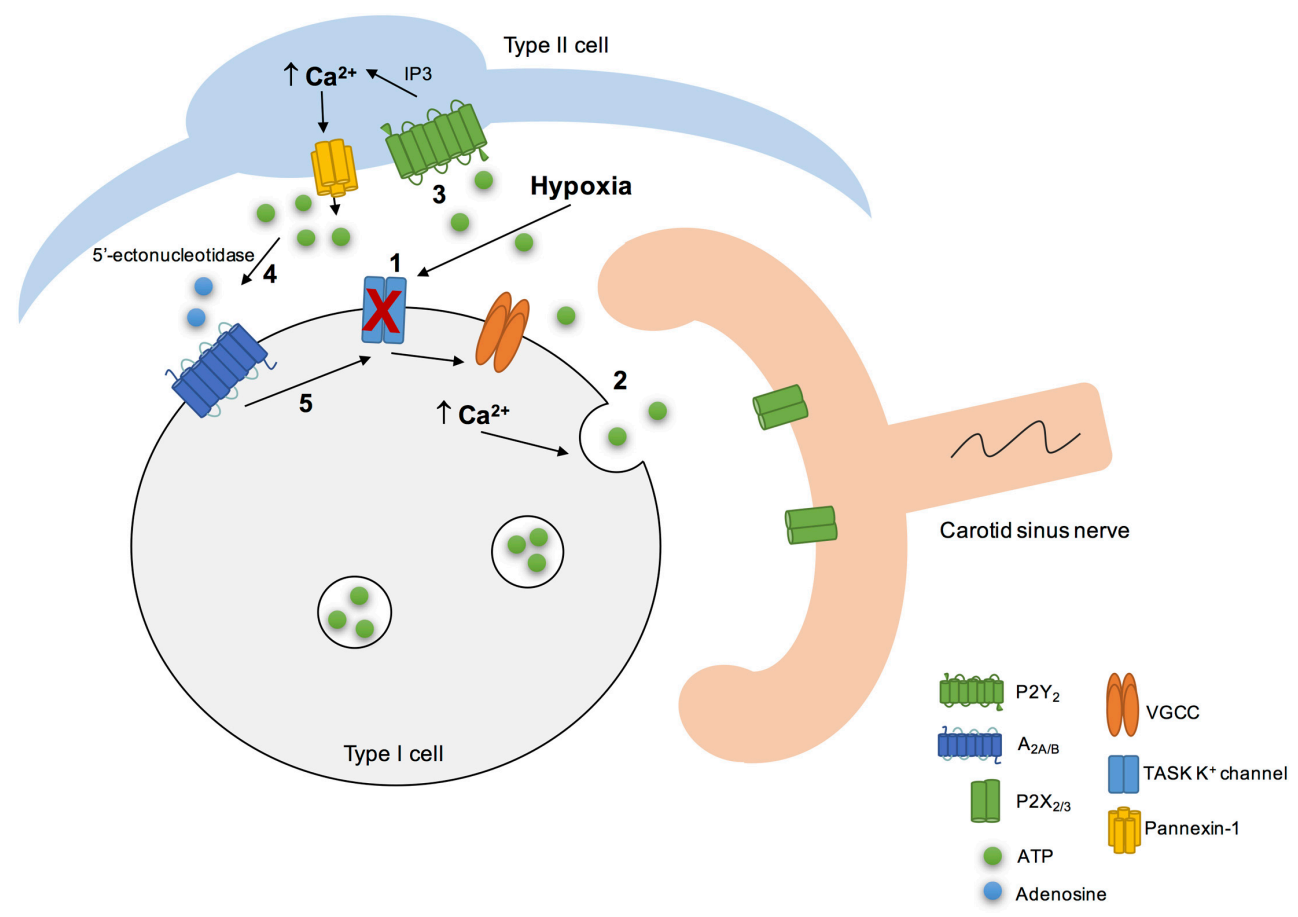

FIGURE 3 | Schematic representation of the CB "tripartite" synapse model proposed by Nurse and collaborators. Hypoxia induced type I cell depolarization through the inhibition of TASK $1 / 3 \mathrm{~K}^{+}$channels (1), leading to $\mathrm{Ca}^{2+}$ entry via voltage-gated $\mathrm{Ca}^{2+}$ channels (VGCC) and to ATP release (2). ATP excites postsynaptic P2X $2 / 3$ receptors on petrosal nerve terminal. ATP can also stimulate $\mathrm{P}_{2} \mathrm{Y}_{2}$ receptors in adjacent type $\|$ cells ( 3 ), leading to the Ca ${ }^{2+}$ release from intracellular stores via inositol triphosphate (IP3) signaling pathways and opening of pannexin-1 channels. This results in ATP release that could be break down by extracellular 5'ectonucleotidase into adenosine (4) (Conde et al., 2012a; Salman et al., 2017). Adenosine stimulates $A_{2 A}$ adenosine receptors in type I cells, leading to the inhibition of TASK1/3 $\mathrm{K}^{+}$channels, that enhance type I cell depolarization (5) (Xu et al., 2005) and, therefore ATP release. It is not represented but hypoxia stimulates adenosine release per se from type I cells (Conde and Monteiro, 2004) and high levels of ATP could inhibit pannexin-1 channels in type II cells and inhibit the chemoreceptor function via P2Y, receptors, through a negative feedback mechanism. Adapted from Zhang et al. (2012), Nurse (2014), Murali and Nurse (2016).

in isolated type II cells (Xu et al., 2003; Tse et al., 2012), since the application of different purinoceptor agonists on dissociated cell cultures of types I and II CB showed that ATP acts on type II cells via $\mathrm{P}_{2} \mathrm{Y}_{2}$ receptors subtype (Xu et al., 2003). Later, it was described that $\mathrm{P}_{2} \mathrm{Y}_{2}$ receptors activation on type II cells lead to an increase in intracellular $\mathrm{Ca}^{2+}$ levels and to a prolonged membrane depolarization due to the opening of large-pore, pannexin-1 channels (Zhang et al., 2012). Moreover, it was also showed in co-cultures of dissociated $\mathrm{CB}$ cells and petrosal neurons that the selective activation of $\mathrm{P}_{2} \mathrm{Y}_{2}$ receptors on type II cells can lead to ATP release through pannexin-1 channels, an effect that was reversibly inhibited by Panx-1 selective blocker, carbenoxolone (Zhang et al., 2012). These results lead to the authors to propose that CB type II cells may function as an ATP signal amplifier and therefore contribute to chemoexcitation through the mechanism of ATP-induced ATP release (Zhang et al., 2012).

More recently, Murali and Nurse (2016) suggested that the crosstalk between CB type I cells and type II cells during chemotransduction is mediated by purinergic signaling. In isolated rat chemoreceptor clusters, it was observed a delayed intracellular $\mathrm{Ca}^{2+}$ elevations in nearby type II cells that was promoted by type I cell depolarization induced by hypoxia, hypercapnia or high $\mathrm{K}^{+}$, an effect blocked by the $\mathrm{P}_{2} \mathrm{Y}_{2}$ antagonist suramin (Murali and Nurse, 2016). In contrast, when $\mathrm{P}_{2} \mathrm{Y}_{2}$ receptors in type II cells were stimulated induced a delayed, secondary intracellular $\mathrm{Ca}^{2+}$ elevations in nearby type I cells, an effect that was blocked by inhibitors of pannexin-1 channels as well as by inhibitor of $\mathrm{A}_{2 \mathrm{~A}}$ adenosine receptors and $5^{\prime}$ ectonucleotidase (Murali and Nurse, 2016). Therefore, this work demonstrated that the ATP released through pannexin-1 channels in type II cells and that is catabolized extracellularly by $5^{\prime}$-ectonucleotidase into adenosine is the principal source of adenosine mediating the crosstalk between types I and II cells (Murali and Nurse, 2016). The adenosine that is produced extracellularly then can stimulate $\mathrm{A}_{2 \mathrm{~A}}$ receptors that are present in type I cells inducing the increase in intracellular $\mathrm{Ca}^{2+}(\mathrm{Xu}$ et al., 2006; Tse et al., 2012; Nurse and Piskuric, 2013). On the postsynaptic side at the CSN nerve endings, adenosine could increase the CSN discharge through the activation of $\mathrm{A}_{2 \mathrm{~A}}$ adenosine receptors on afferent nerve terminals (Conde et al., 2012a). However, since it was observed that even in the presence of AOPCP a residual $\mathrm{Ca}^{2+}$ response in type I cells persists, it cannot be excluded the possibility of type II cells via pannexin1 channels directly release small amounts of adenosine (Murali and Nurse, 2016).

Adenosine-5' -triphosphate itself could also regulate its own extracellular levels at the synapse. High levels of extracellular 


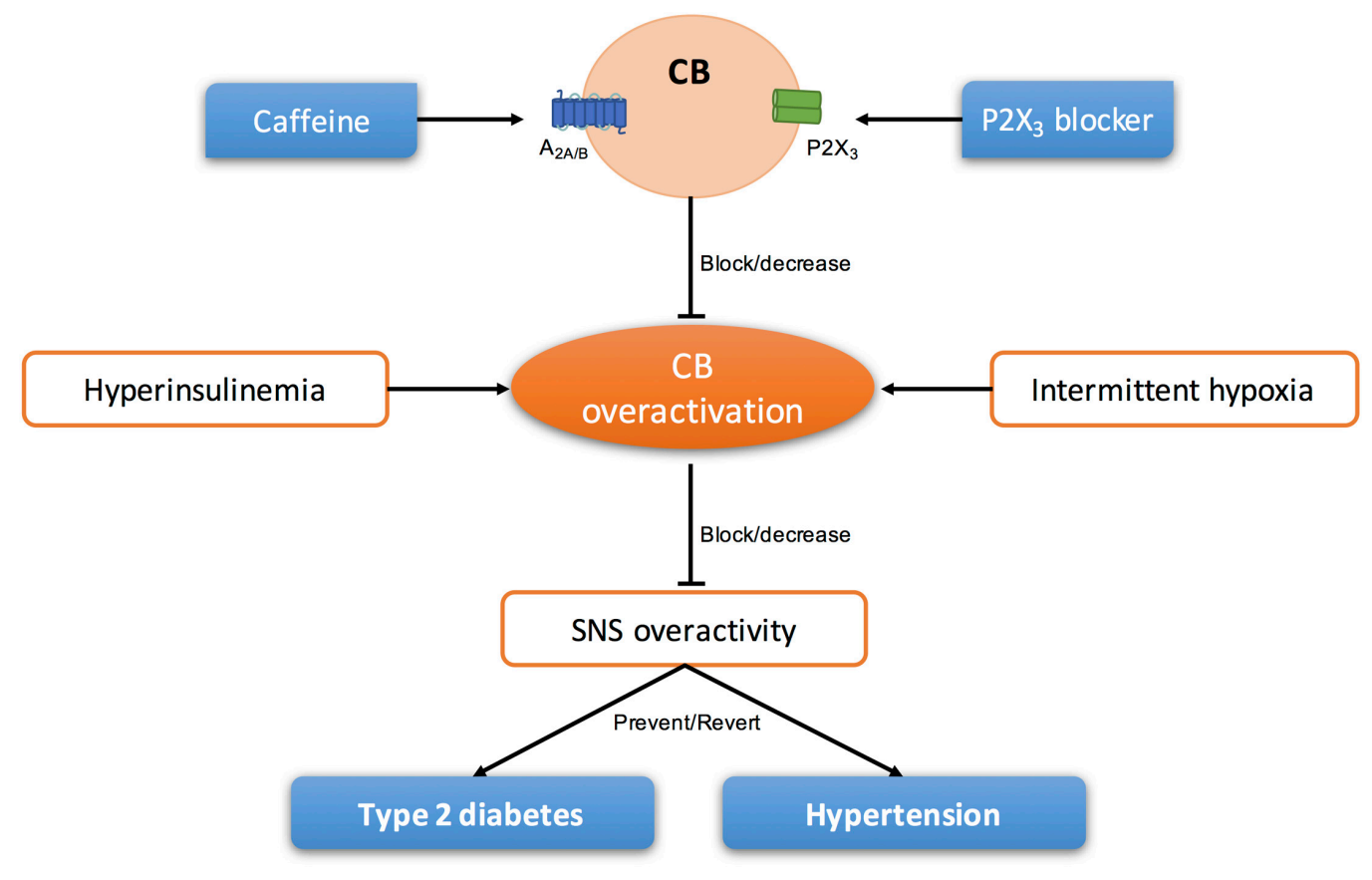

FIGURE 4 | Schematic representation of the modulation of purinergic systems to block/decrease the overactivation of CB present in sympathetic-mediated diseases, as type 2 diabetes and essential hypertension.

ATP could induce a negative feedback loop to inhibit pannexin1 channels thereby regulating ATP release from type II cells (Dubyak, 2009). Additionally, high extracellular levels of ATP did not affect the resting intracellular $\mathrm{Ca}^{2+}$ (Xu et al., 2003) but strongly inhibited the hypoxia-induced elevation in intracellular $\mathrm{Ca}^{2+}$ in type I cells via a negative feedback mechanism involving $\mathrm{P}_{2} \mathrm{Y}_{1}$ receptors (Xu et al., 2005; Tse et al., 2012). The mechanism behind this effect involved the closure of background conductance(s) other than TASK-like $\mathrm{K}^{+}$, maxi-K or $\mathrm{Na}^{+}$channels (Xu et al., 2005; Tse et al., 2012). However, this negative feedback promoted by ATP on type I cells via $\mathrm{P}_{2} \mathrm{Y}_{1}$ could be counteracted by the positive feedback action of adenosine on the presynaptic and/or postsynaptic side. All these findings about the purinergic signaling in the rat $\mathrm{CB}$ leads Colin Nurse group to propose a model of the CB "tripartite" synapse (Figure 3) (Zhang et al., 2012; Piskuric and Nurse, 2013; Nurse, 2014; Murali and Nurse, 2016).

\section{ROLE OF PURINES IN CAROTID BODY-MEDIATED PATHOLOGIES}

In the last years, several literature was published defending the idea that the $\mathrm{CB}$ could be a therapeutic target for the treatment of sympathetically mediated diseases, as $\mathrm{CB}$ activity seems to be increased and involved in the pathogenesis of these diseases (Paton et al., 2013; Iturriaga, 2017). Animal and human studies have suggested the use of unilateral and/or bilateral CB ablation for the treatment of essential hypertension and heart failure (Abdala et al., 2012; Niewinski et al., 2013, 2017; Fudim et al., 2015; Narkiewicz et al., 2016). However, knowing that the surgical resection of the CSN is prone to cause side effects (for a review see Iturriaga, 2017; Sacramento et al., 2017b) other approaches that do not permanently restrict carotid body (CB) function may be more appropriate in the long term. Therefore, modulation of purines levels and/or action could be a strategy to treat pathologies associated with $\mathrm{CB}$ dysfunction (Figure 4).

\section{Type 2 Diabetes}

In 2013, our group demonstrated for the first time that $C B$ regulates peripheral insulin sensitivity and that $\mathrm{CB}$ overactivation is involved in the genesis of hypertension and insulin resistance induced by hypercaloric diets (Ribeiro et al., 2013), an effect that seems to be mediated by a sympathetic nervous system overactivation (Ribeiro et al., 2013; Sacramento et al., 2017b). Moreover, we also showed that insulin triggers CB activation, suggesting that hyperinsulinemia may be one of the stimulus responsible for $\mathrm{CB}$ overactivation leading to sympathetic nervous system overactivity that is associated with metabolic disturbances, such as type 2 diabetes (Ribeiro et al., 2013). In the same work, we described that bilateral CSN resection prevents the development of dysmetabolic changes induced by hypercaloric diets (Ribeiro et al., 2013) and more recently we have demonstrated that bilateral, but not unilateral CSN resection, restores insulin sensitivity and glucose homeostasis in prediabetes and type 2 diabetic rats (Sacramento et al., 2017a,b) suggesting that $\mathrm{CB}$ modulation could be used as a therapeutic approach. 
Knowing that adenosine is one of the key neurotransmitters in the CB (Conde and Monteiro, 2004; Conde et al., 2012a) and that caffeine decreases CB activity acutely (Conde et al., 2006) and chronically (Conde et al., 2012c) by approximately 60\%, it is expected that the overactivation of the $\mathrm{CB}$ seen in hypercaloric animal models could be decreased with long-term administration of caffeine. In fact, our group described that chronic caffeine intake prevents and reverted the increase in blood pressure and insulin resistance in hypercaloric animal models of prediabetes (Conde et al., 2012b). Additionally, epidemiological studies described that chronic caffeine consumption is associated with a significant lower risk of diabetes (van Dam and Hu, 2005; Ding et al., 2014). Therefore, it remains to prove that CB overactivation in hypercaloric animal models of diabetes is decreased in the presence of long-term caffeine treatment as well as the link caffeine-decreased CB activity- decreased sympathetic nervous system activity.

\section{Obstructive Sleep Apnea}

Chronic intermittent hypoxia $(\mathrm{CIH})$, which is characterized by cyclic hypoxic episodes of short duration followed by normoxia, is a characteristic feature of obstructive sleep apnea, the most common form of sleep disorder. The CB has been proposed to be the link between the reflex increase in sympathetic nervous system activity and the blood pressure associated with obstructive sleep apnea due to CIH (Fletcher et al., 1992; Narkiewicz et al., 1999). In fact, an augment in peripheral $\mathrm{CB}$ drive in obstructive sleep apnea patients has been observed, since they showed an increase in ventilatory and cardiovascular reflex responses induced by acute hypoxia (Narkiewicz et al., 1999). This increase in CB drive has been showed to be due to CIH, since Peng et al. (2003) demonstrated that $\mathrm{CIH}$ induced a progressive increase in CSN activity with each hypoxic episode, remaining the baseline activity elevated approximately during $60 \mathrm{~min}$ after the last acute hypoxic stimuli, an effect called sensory long-term facilitation. These authors also suggested that sensory long-term facilitation contributes to the persistent increase in sympathetic nervous activity and blood pressure that is observed in obstructive sleep apnea, since the increase in $\mathrm{CB}$ sensory activity triggers sympathetic nerve discharge and an increase in blood pressure (Peng et al., 2003). Recently, our group showed that adenosine is one of the mediators involved in the sensitization of $\mathrm{CB}$ during $\mathrm{CIH}$ (Sacramento et al., 2015), since caffeine decreased basal and hypoxia-evoked $\left(5 \% \mathrm{O}_{2}\right)$ CSN chemosensory activity in rats subjected to 15 days of $\mathrm{CIH}$ (Sacramento et al., 2015). Moreover, it has been described that adenosine levels are augmented in obstructive sleep apnea patients (Lavie, 2003) suggesting a deregulation of adenosinergic system in sleep apnea patients. Therefore, the blockage of adenosine receptors in the $\mathrm{CB}$ or modulation of adenosine metabolism both in the $\mathrm{CB}$ and peripherally might be useful to treat some of the pathophysiological features of chronic obstructive sleep apnea.

\section{Hypertension}

Hypertension affects one-third of the human population and in the United States only 53\% of those tacking antihypertensive medication have their condition controlled (Go et al., 2014). Furthermore, it is estimated that $14-16 \%$ of all patients with hypertension are resistant to antihypertensive medication and/or having poor compliance or tolerance to the medication (Achelrod et al., 2015). It is accepted that CB chemoreflexevoked sympathetic activity responses are increased in human patients and animal models of systemic essential hypertension (Trzebski et al., 1982; Somers et al., 1988; Tan et al., 2010; Abdala et al., 2012; Siński et al., 2012) and therefore the $\mathrm{CB}$ has been proposed as a therapeutic target for the treatment of cardiovascular diseases. Accordingly, CB ablation was capable of control the development and maintenance of high blood pressure in spontaneously hypertensive rats and humans (Abdala et al., 2012; Narkiewicz et al., 2016). However, the effect of unilateral ablation CB in hypertensive patients has diminished efficacy 12 months after ablation, suggesting a compensation of the remaining CB (Narkiewicz et al., 2016), suggesting that other approaches are needed to modulate $\mathrm{CB}$ function in cardiovascular diseases. Pijacka et al. (2016) demonstrated an upregulation of the $\mathrm{P}_{2} \mathrm{X}_{3}$ mRNA in the chemoreceptive petrosal sensory neurons of spontaneously hypertensive rats and that $\mathrm{P}_{2} \mathrm{X}_{3}$ receptors are present in human $\mathrm{CB}$ from individuals with a medical history of hypertension. Moreover, it has also shown that a $\mathrm{P}_{2} \mathrm{X}_{3}$ receptor antagonist is capable to decrease sympathetic activity and arterial pressure in spontaneously hypertensive rats, an effect that was absent in normotensive animals (Pijacka et al., 2016). All these data suggest that ATP is responsible for the $\mathrm{CB}$ hyperactivity and hyperreflexia seen in essential hypertension and that support the modulation of $\mathrm{P}_{2} \mathrm{X}_{3}$ receptor as non-surgical a non-surgical strategy to control human hypertension. Although, apart from $\mathrm{P}_{2} \mathrm{X}_{3}$ receptor, and knowing that $\mathrm{P}_{2} \mathrm{X}_{4}$ receptors are expressed post-synaptically in the CB (Campanucci et al., 2006) and that they are involved in ventrolateral medulla control of the sympathetic autonomic function (Zoccal et al., 2011), we can postulate that modulation of $\mathrm{P}_{2} \mathrm{X}_{4}$ receptors might be a therapeutic target for hypertension.

\section{AUTHOR CONTRIBUTIONS}

All authors listed have made a substantial, direct and intellectual contribution to the work, and approved it for publication.

\section{ACKNOWLEDGMENT}

JS is supported by Ph.D. Grant from the Portuguese Foundation for Science and Technology, PD/BD/105890/2014. 


\section{REFERENCES}

Abbracchio, M. P., and Burnstock, G. (1994). Purinoceptors: Are there families of P2X and P2Y purinoceptors? Pharmacol. Ther. 64, 445-475. doi: 10.1016/01637258(94)00048-4

Abdala, A. P., McBryde, F. D., Marina, N., Hendy, E. B., Engelman, Z. J., Fudim, M., et al. (2012). Hypertension is critically dependent on the carotid body input in the spontaneously hypertensive rat. J. Physiol. 590, 4269-4277. doi: 10.1113/ jphysiol.2012.237800

Achelrod, D., Wenzel, U., and Frey, S. (2015). Systematic review and meta-analysis of the prevalence of resistant hypertension in treated hypertensive populations. Am. J. Hypertens. 28, 355-361. doi: 10.1093/ajh/hpu151

Acker, H., and Starlinger, H. (1984). Adenosine triphosphate content in the cat carotid body under different arterial $\mathrm{O}_{2}$ and $\mathrm{CO}_{2}$ conditions. Neurosci. Lett. 50, 175-179. doi: 10.1016/0304-3940(84)90482-8

Alcayaga, J., Cerpa, V., Retamal, M., Arroyo, J., Iturriaga, R., and Zapata, P. (2000). Adenosine triphosphate-induced peripheral nerve discharges generated from the cat petrosal ganglion in vitro. Neurosci. Lett. 282, 185-188. doi: 10.1016/ S0304-3940(00)00896-X

Anichkov, S. V., and Belen'kii, M. L. (1963). Pharmacology of the Carotid Body Chemoreceptors. Oxford: Pergamon Press Ltd.

Arch, J. R., and Newsholme, E. A. (1978). Activities and some properties of 5 '-nucleotidase, adenosine kinase and adenosine deaminase in tissues from vertebrates and invertebrates in relation to the control of the concentration and the physiological role of adenosine. Biochem. J. 174, 965-977. doi: 10.1042/ bj1740965

Bairam, A., Joseph, V., Lajeunesse, Y., and Kinkead, R. (2009). Altered expression of adenosine $\mathrm{A} 1$ and $\mathrm{A} 2 \mathrm{~A}$ receptors in the carotid body and nucleus tractus solitarius of adult male and female rats following neonatal caffeine treatment. Brain Res. 1287, 74-83. doi: 10.1016/j.brainres.2009.06.064

Berne, R. M., Rubio, R., and Curnish, R. R. (1974). Release of adenosine from ischemic brain: effect on cerebral vascular resistance and incorporation into cerebral adenine nucleotides. Circ. Res. 35, 262-271. doi: 10.1161/01.RES.35. 2.262

Bodin, P., and Burnstock, G. (2001). Purinergic signalling: ATP release. Neurochem. Res. 26, 959-969. doi: 10.1023/A:1012388618693

Boué-Grabot, E., and Pankratov, Y. (2017). Modulation of central synapses by astrocyte-released ATP and postsynaptic P2X receptors. Neural Plast. 2017:454275. doi: 10.1155/2017/9454275

Broch, O. J., and Ueland, P. M. (1980). Regional and subcellular distribution of S-adenosylhomocysteine hydrolase in the adult rat brain. J. Neurochem. 35, 484-488. doi: 10.1111/j.1471-4159.1980.tb06291.x

Buckler, K. J. (2015). TASK channels in arterial chemoreceptors and their role in oxygen and acid sensing. Pflugers Arch. 467, 1013-1025. doi: 10.1007/s00424015-1689- 1

Burnstock, G. (1972). Purinergic nerves. Pharmacol. Rev. 24, 509-581.

Burnstock, G. (2016). Short- and long-term (trophic) purinergic signalling. Philos. Trans. R. Soc. Lond. B. Biol. Sci. 371:20150422. doi: 10.1098/rstb.2015.0422

Burnstock, G., Campbell, G., Satchell, D., and Smythe, A. (1970). Evidence that adenosine triphosphate or a related nucleotide is the transmitter substance released by non-adrenergic inhibitory nerves in the gut. Br. J. Pharmacol. 40, 668-688. doi: 10.1111/j.14765381.1997.tb06815.x

Burnstock, G., Dumsday, B., and Smythe, A. (1972). Atropine resistant excitation of the urinary bladder: the possibility of transmission via nerves releasing a purine nucleotide. Br. J. Pharmacol. 44, 451-461. doi: 10.1111/j.1476-5381. 1972.tb07283.x

Burnstock, G., and Knight, G. E. (2004). Cellular distribution and functions of $\mathrm{P} 2$ receptor subtypes in different systems. Int. Rev. Cytol. 240, 31-304. doi: 10.1016/S0074-7696(04)40002-3

Buttigieg, J., and Nurse, C. A. (2004). Detection of hypoxia-evoked ATP release from chemoreceptor cells of the rat carotid body. Biochem. Biophys. Res. Commun. 322, 82-87. doi: 10.1016/j.bbrc.2004.07.081

Campanucci, V. A., Zhang, M., Vollmer, C., and Nurse, C. A. (2006). Expression of multiple $\mathrm{P} 2 \mathrm{X}$ receptors by glossopharyngeal neurons projecting to rat carotid body $\mathrm{O}_{2}$-chemoreceptors: role in nitric oxide-mediated efferent inhibition. J. Neurosci. 26, 9482-9493. doi: 10.1523/JNEUROSCI.1672-06. 2006
Cass, C. E., Young, J. D., and Baldwin, S. A. (1998). Recent advances in the molecular biology of nucleoside transport of mammalian cells. Biochem. Cell Biol. 76, 761-770. doi: 10.1139/098-095

Conde, S. V., Gonzalez, C., Batuca, J. R., Monteiro, E. C., and Obeso, A. (2008). An antagonistic interaction between A2B adenosine and D2 dopamine receptors modulates the function of rat carotid body chemoreceptor cells. J. Neurochem.107, 1369-1381. doi: 10.1111/j.1471-4159.2008.05704.x

Conde, S. V., and Monteiro, E. C. (2004). Hypoxia induces adenosine release from the rat carotid body. J. Neurochem. 89, 1148-1156. doi: 10.1111/j.1471-4159. 2004.02380.x

Conde, S. V., and Monteiro, E. C., (2006). Profiles for ATP and adenosine release at the carotid body in response to $\mathrm{O}_{2}$ concentrations. Adv. Exp. Med. Biol. 580, 179-184. doi: 10.1007/0-387-31311-7_27

Conde, S. V., Monteiro, E. C., Obeso, A., and Gonzalez, C. (2009). Adenosine in peripheral chemoreception: new insights into a historically overlooked molecule - invited article. Adv. Exp. Med. Biol. 648, 145-159. doi: 10.1007/97890-481-2259-2_17

Conde, S. V., Monteiro, E. C., Rigual, R., Obeso, A., and Gonzalez, C. (2012a). Hypoxic intensity: a determinant for the contribution of ATP and adenosine to the genesis of carotid body chemosensory activity. J. Appl. Physiol. 112, 2002-2010. doi: 10.1152/japplphysiol.01617.2011

Conde, S. V., Nunes da Silva, T., Gonzalez, C., Mota Carmo, M., Monteiro, E. C., and Guarino, M. P. (2012b). Chronic caffeine intake decreases circulating catecholamines and prevents diet-induced insulin resistance and hypertension in rats. Br. J. Nutr. 107, 86-95. doi: 10.1017/S0007114511002406

Conde, S. V., Obeso, A., Vicario, I., Rigual, R., Rocher, A., and Gonzalez, C. (2006). Caffeine inhibition of rat carotid body chemoreceptors is mediated by A2A and A2B adenosine receptors. J. Neurochem. 98, 616-628. doi: 10.1111/j.1471-4159. 2006.03912.x

Conde, S. V., Ribeiro, M. J., Obeso, A., Rigual, R., Monteiro, E. C., and Gonzalez, C. (2012c). Chronic caffeine intake in adult rat inhibits carotid body sensitization produced by chronic sustained hypoxia but maintains intact chemoreflex output. Mol. Pharmacol. 82, 1056-1065. doi: 10.1124/mol.112.081216

Chen, J., Dinger, B., and Fidone, S. J. (1997). cAMP production in rabbit carotid body: role of adenosine. J. Appl. Physiol. 82, 1771-1775.

Ding, M., Bhupathiraju, S. N., Chen, M., van Dam, R. M., and Hu, F. B. (2014). Caffeinated and decaffeinated coffee consumption and risk of type 2 diabetes: a systematic review and a dose-response meta-analysis. Diabetes Care 37, 569-586. doi: $10.2337 / \mathrm{dc} 13-1203$

Donnelly, D. F., and Doyle, T. P. (1994). Developmental changes in hypoxiainduced catecholamine release from rat carotid body, in vitro. J. Physiol. 475, 267-275. doi: 10.1113/jphysiol.1994.sp020067

Dontas, A. S. (1955). Effects of energy donors, metabolic inhibitors and substrates on chemoreceptor activity. J. Pharmacol. Exp. Ther. 115, 46-54.

Dubyak, G. R. (2009). Both sides now: multiple interactions of ATP with pannexin1 hemichannels. Focus on "A permeant regulating its permeation pore: inhibition of pannexin 1 channels by ATP”. Am. J. Physiol. Cell. Physiol. 296, C235-C241. doi: 10.1152/ajpcell.00639.2008

Fitzgerald, R. S. (2000). Oxygen and carotid body chemotransduction: the cholinergic hypothesis - a brief history and new evaluation. Respir. Physiol. 120, 89-104. doi: 10.1016/S0034-5687(00)00091-8

Fletcher, E. C., Lesske, J., Qian, W., Miller, C. C., and Unger, T. (1992). Repetitive, episodic hypoxia causes diurnal elevation of blood pressure in rats. Hypertension 19, 555-561. doi: 10.1161/01.HYP.19.6.555

Fredholm, B. B., Abbracchio, M. P., Burnstock, G., Daly, J. W., Harden, T. K., Jacobson, K. A., et al. (1994). Nomenclature and classification of purinoceptors. Pharmacol. Rev. 46, 143-156.

Fredholm, B. B., Bättig, K., Holmén, J., Nehlig, A., and Zvartau, E. E. (1999). Actions of caffeine in the brain with special reference to factors that contribute to its widespread use. Pharmacol. Rev. 51, 83-133.

Fredholm, B. B., IJzerman, A. P., Jacobson, K. A., Klotz, K. N., and Linden, J. (2001). International union of pharmacology. XXV. Nomenclature and classification of adenosine receptors. Pharmacol. Rev. 53, 527-552.

Fudim, M., Groom, K. L., Laffer, C. L., Netterville, J. L., Robertson, D., and Elijovich, F. (2015). Effects of carotid body tumor resection on the blood pressure of essential hypertensive patients. J. Am. Soc. Hypertens. 9, 435-442. doi: 10.1016/j.jash.2015.03.006 
Fuxe, K., Canals, M., Torvinen, M., Marcellino, D., Terasmaa, A., Genedani, S., et al. (2007). Intramembrane receptor-receptor interactions: a novel principle in molecular medicine. J. Neural. Transm. 114, 49-75. doi: 10.1007/s00702-0060589-0

Gauda, E. B. (2002). Gene expression in peripheral arterial chemoreceptors. Microsc. Res. Tech. 59, 153-167. doi: 10.1002/jemt.10190

Gauda, E. B., Bamford, O., and Gerfen, C. R. (1996). Developmental expression of tyrosine hydroxylase, D2-dopamine receptor and substance $\mathrm{P}$ genes in the carotid body of the rat. Neuroscience 75, 969-977. doi: 10.1016/0306-4522(96) 00312-0

Gauda, E. B., Northington, F. J., Linden, J., and Rosin, D. L. (2000). Differential expression of $\mathrm{A}_{2 a}, \mathrm{~A}_{1}$-adenosine and $\mathrm{D}_{2}$-dopamine receptor genes in rat peripheral arterial chemoreceptors during postnatal development. Brain Res. 28, 1-10. doi: 10.1016/S0006-8993(00)02314-3

Go, A. S., Mozaffarian, D., Roger, V. L., Benjamin, E. J., Berry, J. D., Blaha, M. J., et al. (2014). Executive summary: heart disease and stroke statistics-2014 update: a report from the American Heart Association. Circulation 129, 399-410. doi: 10.1161/01.cir.0000442015.53336.12

Gonzalez, C., Agapito, M. T., Rocher, A., Gomez-Niño, A., Rigual, R., Castañeda, J., et al. (2010). A revisit to $\mathrm{O}_{2}$ sensing and transduction in the carotid body chemoreceptors in the context of reactive oxygen species biology. Respir. Physiol. Neurobiol. 174, 317-330. doi: 10.1016/j.resp.2010.09.002

Gonzalez, C., Almaraz, L., Obeso, A., and Rigual, R. (1994). Carotid body chemoreceptors: from natural stimuli to sensory discharges. Physiol. Rev. 74, 829-898.

Gordon, G. R., Baimoukhametova, D. V., Hewitt, S. A., Rajapaksha, W. R., Fisher, T. E., and Bains, J. S. (2005). Norepinephrine triggers release of glial ATP to increase postsynaptic efficacy. Nat. Neurosci. 8, 1078-1086. doi: 10.1038/nn1498

Griffith, D. A., and Jarvis, S. M. (1996). Nucleoside and nucleobase transport systems of mammalian cells. Biochim. Biophys. Acta 1286, 153-181. doi: 10.1016/S0304-4157(96)00008-1

Hatton, C. J., and Peers, C. (1996). Hypoxic inhibition of $\mathrm{K}^{+}$currents in isolated rat type I carotid body cells: evidence against the involvement of cyclic nucleotides. Pflugers Arch. 433, 129-135. doi: 10.1007/s004240050258

Holmes, A. P., Ray, C. J., Pearson, S. A., Coney, A. M., and Kumar, P. (2017). Ecto-5'-nucleotidase (CD73) regulates peripheral chemoreceptor activity and cardiorespiratory responses to hypoxia. J. Physiol. doi: 10.1113/JP274498 [Epub ahead of print].

Hoshino, T., Yamada, K., Masuoka, K., Tsuboi, I., Itoh, K., Nonaka, K., et al. (1994). Elevated adenosine deaminase activity in the serum of patients with diabetes mellitus. Diabetes Res. Clin. Pract. 25, 97-102. doi: 10.1016/0168-8227(94) 90034- 5

Howell, L. L., and Landrum, A. M. (1995). Attenuation of hypoxia-induced increases in ventilation by adenosine antagonists in rhesus monkeys. Life Sci. 57, 773-783. doi: 10.1016/0024-3205(95)02005-4

Iturriaga, R. (2017). Translating carotid body function into clinical medicine. J. Physiol. doi: 10.1113/JP275335 [Epub ahead of print].

Iturriaga, R., and Alcayaga, J. (2004). Neurotransmission in the carotid body: transmitters and modulators between glomus cells and petrosal ganglion nerve terminals. Brain Res. Brain Res. Rev. 47, 46-53. doi: 10.1016/j.brainresrev.2004. 05.007

Jarisch, A., Landgren, S., Neil, E., and Zotterman, Y. (1952). Impulse activity in the carotid sinus nerve following intra-carotid injection of potassium chloride, veratrine, sodium citrate, adenosine-triphosphate and alpha-dinitrophenol. Acta Physiol. Scand. 25, 195-211. doi: 10.1111/j.1748-1716.1952.tb00872.x

Jo, Y. H., and Role, L. W. (2002). Coordinate release of ATP and GABA at in vitro synapses of lateral hypothalamic neurons. J. Neurosci. 22, 4794-4804.

Jo, Y. H., and Schlichter, R. (1999). Synaptic corelease of ATP and GABA in cultured spinal neurons. Nat. Neurosci. 2, 241-245. doi: 10.1038/6344

Khakh, B. S., and North, R. A. (2006). P2X receptors as cell-surface ATP sensors in health and disease. Nature 442, 527-532. doi: 10.1038/nature04886

Khakh, B. S., and North, R. A. (2012). Neuromodulation by extracellular ATP and P2X receptors in the CNS. Neuron 76, 51-69. doi: 10.1016/j.neuron.2012.09.024

Kobayashi, S. (1976). An autoradiographic study of the mouse carotid body using tritiated leucine dopa, dopamine and ATP with special reference to the chief cell as a paraneuron. Arch. Histol. Jpn. 39, 295-317. doi: 10.1679/aohc1950. 39.295
Kobayashi, S., Conforti, L., and Millhorn, D. E. (2000). Gene expression and function of A2A receptor in the rat carotid body. Am. J. Physiol. Lung Cell Mol. Physiol. 279, L273-L282.

Knowles, A. F. (2011). The GDA1_CD39 superfamily: NTPDases with diverse functions. Purinergic Signal. 7, 21-45. doi: 10.1007/s11302-010-9214-7

Lavie, L. (2003). Obstructive sleep apnoea syndrome - an oxidative stress disorder. Sleep Med. Rev. 7, 35-51. doi: 10.1053/smrv.2002.0261

Lewis, C., Neidhart, S., Holy, C., North, R. A., Buell, G., and Surprenant, A. (1995). Coexpression of P2X2 and P2X3 receptor subunits can account for ATP-gated currents in sensory neurons. Nature 377, 432-435. doi: 10.1038/377 $432 \mathrm{a} 0$

Livermore, S., and Nurse, C. A. (2013). Enhanced adenosine A2b receptor signaling facilitates stimulus-induced catecholamine secretion in chronically hypoxic carotid body type I cells. Am. J. Physiol. Cell Physiol. 305, C739-C750. doi: 10.1152/ajpcell.00137.2013

López-López, J. R., De Luis, D. A., and Gonzalez, C. (1993). Properties of a transient $\mathrm{K}^{+}$current in chemoreceptor cells of rabbit carotid body. J. Physiol. 460, 15-32. doi: 10.1113/jphysiol.1993.sp019456

Marshall, J. M. (1994). Peripheral chemoreceptors and cardiovascular regulation. Physiol. Rev. 74, 543-594.

Maxwell, D., Fuller, R. W., Conradson, T. B., Dixon, C. M., Aber, V., Hughes, J. M., et al. (1987). Contrasting effects of two xanthines, theophylline and enprofylline, on the cardiorespiratory stimulation of infused adenosine in man. Acta Physiol. Scand. 131, 459-465. doi: 10.1111/j.1748-1716.1987.tb08262.x

Maxwell, D., Fuller, R. W., Nolop, K. B., Dixon, C. M., and Hughes, J. M. (1986). Effects of adenosine on ventilatory responses to hypoxia and hypercapnia in humans. J. Appl. Physiol. 61, 1762-1766.

McQueen, D. S., Bond, S. M., Moores, C., Chessell, I., Humphrey, P. P. A., and Dowd, E. (1998). Activation of P2Xreceptors for adenosine triphosphate evokes cardiorespiratory reflexes in anaesthetized rats. J. Physiol. 507, 843-855. doi: 10.1111/j.1469-7793.1998.843bs.x

McQueen, D. S., and Ribeiro, J. A. (1981). Effect of adenosine on carotid chemoreceptor activity in the cat. Br. J. Pharmacol. 74, 129-136. doi: 10.1111/j. 1476-5381.1981.tb09964.x

McQueen, D. S., and Ribeiro, J. A. (1983). On the specificity and type of receptor involved in carotid body chemoreceptor activation by adenosine in the cat. $\mathrm{Br}$. J. Pharmacol. 80, 347-354. doi: 10.1111/j.1476-5381.1983.tb10040.x

McQueen, D. S., and Ribeiro, J. A. (1986). Pharmacological characterization of the receptor involved in chemoexcitation induced by adenosine. $\mathrm{Br}$. J. Pharmacol. 88, 615-620. doi: 10.1111/j.1476-5381.1986.tb10242.x

Monteiro, E. C., and Ribeiro, J. A. (1987). Ventilatory effects of adenosine mediated by carotid body chemoreceptors in the rat. Naunyn Schmiedebergs Arch. Pharmacol. 335, 143-148.

Monteiro, E. C., and Ribeiro, J. A. (1989). Adenosine deaminase and adenosine uptake inhibitions facilitate ventilation in rats. Naunyn Schmiedebergs Arch. Pharmacol. 340, 230-238.

Monteiro, E. C., and Ribeiro, J. A. (2000). Adenosine-dopamine interactions and ventilation mediated through carotid body chemoreceptors. Adv. Exp. Med. Biol. 475, 671-684. doi: 10.1007/0-306-46825-5_66

Monteiro, E. C., Vera-Cruz, P., Monteiro, T. C., and Silva e Sousa, M. A. (1996). Adenosine increases the cAMP content of the rat carotid body in vitro. $A d v$. Exp. Med. Biol. 410, 299-303. doi: 10.1007/978-1-4615-5891-0_45

Murali, S., and Nurse, C. A. (2016). Purinergic signalling mediates bidirectional crosstalk between chemoreceptor type I and glial-like type II cells of the rat carotid body. J. Physiol. 594, 391-406. doi: 10.1113/JP271494

Narkiewicz, K., Ratcliffe, L. E., Hart, E. C., Briant, L. J., Chrostowska, M., Wolf, J., et al. (2016). Unilateral carotid body resection in resistant hypertension: a safety and feasibility trial. JACC Basic Transl. Sci. 1, 313-324. doi: 10.1016/j.jacbts. 2016.06.004

Narkiewicz, K., van de Borne, P. J., Pesek, C. A., Dyken, M. E., Montano, N., and Somers, V. K. (1999). Selective potentiation of peripheral chemore- flex sensitivity in obstructive sleep apnea. Circulation 99, 1183-1189. doi: 10.1161/ 01.CIR.99.9.1183

Niane, L. M., Donnelly, D. F., Joseph, V., and Bairam, A. (2011). Ventilatory and carotid body chemoreceptor responses to purinergic $\mathrm{P} 2 \mathrm{X}$ receptor antagonists in newborn rats. J. Appl. Physiol. 110, 83-94. doi: 10.1152/japplphysiol.00871. 2010 
Niewinski, P., Janczak, D., Rucinski, A., Jazwiec, P., Sobotka, P. A., Engelman, Z. J., et al. (2013). Carotid body removal for treatment of chronic systolic heart failure. Int. J. Cardiol. 168, 2506-2509. doi: 10.1016/j.ijcard.2013.03.011

Niewinski, P., Janczak, D., Rucinski, A., Tubek, S., Engelman, Z. J., Piesiak, P., et al. (2017). Carotid body resection for sympathetic modulation in systolic heart failure: results from first-in-man study. Eur. J. Heart Fail. 19, 391-400. doi: 10.1002/ejhf.641

North, R. A. (2016). P2X receptors. Philos. Trans. R. Soc. Lond. B Biol. Sci. 371:20150427. doi: 10.1098/rstb.2015.0427

Nunes, A. R., Holmes, A. P., Conde, S. V., Gauda, E. B., and Monteiro, E. C. (2014). Revisiting cAMP signaling in the carotid body. Front. Physiol. 5:406. doi: $10.3389 /$ fphys.2014.0040

Nurse, C. A. (2010). Neurotransmitter and neuromodulatory mechanisms at peripheral arterial chemoreceptors. Exp. Physiol. 95, 657-667. doi: 10.1113/ expphysiol.2009.049312

Nurse, C. A. (2014). Synaptic and paracrine mechanisms at carotid body arterial chemoreceptors. J. Physiol. 592, 3419-3426. doi: 10.1113/jphysiol.2013.269829

Nurse, C. A., and Piskuric, N. A. (2013). Signal processing at mammalian carotid body chemoreceptors. Semin. Cell Dev. 24, 22-30. doi: 10.1016/j.semcdb.2012. 09.006

Obeso, A., Almaraz, L., and González, C. (1985). Correlation between adenosine triphosphate levels, dopamine release and electrical activity in the carotid body: support for the metabolic hypothesis of chemoreception. Brain Res. 348, 64-68. doi: 10.1016/0006-8993(85)90360-9

Obeso, A., Almaraz, L., and González, C. (1989). Effects of cyanide and uncouplers on chemoreceptor activity and ATP content of the cat carotid body. Brain Res. 481, 250-257. doi: 10.1016/0006-8993(89)90801-9

Oliveira, L., Correia, A., Cristina Costa, A., Guerra-Gomes, S., Ferreirinha, F., Magalhães-Cardoso, M. T., et al. (2015). Deficits in endogenous adenosine formation by ecto-5'-nucleotidase/CD73 impair neuromuscular transmission and immune competence in experimental autoimmune myasthenia gravis. Mediators Inflamm. 2015:460610. doi: 10.1155/2015/460610

Pankratov, Y., Lalo, U., Castro, E., Miras-Portugal, M. T., and Krishtal, O. (1999). ATP receptor-mediated component of the excitatory synaptic transmission in the hippocampus. Prog. Brain Res. 120, 237-249. doi: 10.1016/S0079-6123(08) 63559-1

Pardal, R., Ortega-Sáenz, P., Durán, R., and López-Barneo, J. (2007). Glia-like stem cells sustain physiologic neurogenesis in the adult mammalian carotid body. Cell 131, 364-377. doi: 10.1016/j.cell.2007.07.043

Paton, J. F., Sobotka, P. A., Fudim, M., Engelman, Z. J., Hart, E. C., McBryde, F. D., et al. (2013). The carotid body as a therapeutic target for the treatment of sympathetically mediated diseases. Hypertension 61, 5-13. doi: 10.1161/ HYPERTENSIONAHA.111.00064

Peers, C., and Buckler, K. J. (1995). Transduction of chemostimuli by the type I carotid body cell. J. Membr. Biol. 144, 1-9. doi: 10.1007/BF00238411

Peng, Y. J., Overholt, J. L., Kline, D., Kumar, G. K., and Prabhakar, N. R. (2003). Induction of sensory long-term facilitation in the carotid body by intermittent hypoxia: implications for recurrent apneas. Proc. Natl. Acad. Sci. U.S.A. 100, 10073-10078. doi: 10.1073/pnas. 1734109100

Pérez-García, M. T., Almaraz, L., and González, C. (1990). Effects of different types of stimulation on cyclic AMP content in the rabbit carotid body: functional significance. J. Neurochem. 55, 1287-1293. doi: 10.1111/j.1471-4159. 1990.tb03137.x

Pijacka, W., Moraes, D. J., Ratcliffe, L. E., Nightingale, A. K., Hart, E. C., da Silva, M. P., et al. (2016). Purinergic receptors in the carotid body as a new drug target for controlling hypertension. Nat. Med. 22, 1151-1159. doi: 10.1038/nm. 4173

Piskuric, N. A., and Nurse, C. A. (2013). Expanding role of ATP as a versatile messenger at carotid and aortic body chemoreceptors. J. Physiol. 591, 415-422. doi: 10.1113/jphysiol.2012.234377

Podgorska, M., Kocbuch, K., and Pawelczyk, T. (2005). Recent advances in studies on biochemical and structural properties of equilibrative and concentrative nucleoside transporters. Act. Biochem. Pol. 52, 749-758.

Pougnet, J. T., Toulme, E., Martinez, A., Choquet, D., Hosy, E., and BouéGrabot, E. (2014). ATP P2X receptors downregulate AMPA receptor trafficking and postsynaptic efficacy in hippocampal neurons. Neuron 83, 417-430. doi: 10.1016/j.neuron.2014.06.005
Prasad, M., Fearon, I. M., Zhang, M., Laing, M., Vollmer, C., and Nurse, C. A. (2001). Expression of P2X2 and P2X3 receptor subunits in rat carotid body afferent neurones: role in chemosensory signalling. J. Physiol. 537, 667-677. doi: 10.1111/j.1469-7793.2001.00667.x

Ralevic, V., and Burnstock, G. (1998). Receptors for purines and pyrimidines. Pharmacol. Rev. 50, 413-492.

Reyes, E. P., Fernández, R., Larraín, C., and Zapata, P. (2007). Effects of combined cholinergic-purinergic block upon cat carotid body chemosensory activity and ventilatory chemoreflexes. Respir. Physiol. Neurobiol. 156, 23-32. doi: 10.1016/ j.resp.2006.07.006

Ribeiro, J. A., and McQueen, D. S. (1984). "Effects of purines on carotid chemoreceptors", in The Peripheral Arterial Chemoreceptors, ed. D.J. Pallot (London: Croom Helm), 383-390.

Ribeiro, J. A., and Monteiro, E. C. (1991). On the adenosine receptor involved in the excitatory action of adenosine on respiration: ant- agonist profile. Nucleosides Nucleotides 10, 945-953. doi: 10.1080/07328319108047232

Ribeiro, M. J., Sacramento, J. F., Gonzalez, C., Guarino, M. P., Monteiro, E. C., and Conde, S. V. (2013). Carotid body denervation prevents the development of insulin resistance and hypertension induced by hypercaloric diets. Diabetes Metab. Res. Rev. 62, 2905-2916. doi: 10.2337/db12-1463

Rocher, A., Gonzalez, C., and Almaraz, L. (1999). Adenosine inhibits L-type Ca2+ currents and catecholamine release in the rabbit carotid body chemoreceptor cells. Eur. J. Neurosci. 11, 673-681. doi: 10.1046/j.1460-9568.1999.00470

Rong, W., Gourine, A. V., Cockayne, D. A., Xiang, Z., Ford, A. P., Spyer, K. M., et al. (2003). Pivotal role of nucleotide P2X2 receptor subunit of the ATPgated ion channel mediating ventilatory responses to hypoxia. J. Neurosci. 23, $11315-11321$.

Runold, M., Cherniack, N. S., and Prabhakar, N. R. (1990). Effect of adenosine on isolated and superfused cat carotid body activity. Neurosci. Lett. 113, 111-114. doi: 10.1016/0304-3940(90)90504-3

Sacramento, J. F., Chew, D. J., Melo, B. F., Donegá, M., Dopson, W., Guarino, M. P., et al. (2017a). Bioelectronic modulation of carotid sinus nerve activity in the rat: a potential therapeutic approach for type 2 diabetes. Diabetologia (in press).

Sacramento, J. F., Gonzalez, C., Gonzalez-Martin, M. C., and Conde, S. V. (2015). Adenosine receptor blockade by caffeine inhibits carotid sinus nerve chemosensory activity in chronic intermittent hypoxic animals. Adv. Exp. Med. Biol. 860, 133-137. doi: 10.1007/978-3-319-18440-1_15

Sacramento, J. F., Ribeiro, M. J., Rodrigues, T., Olea, E., Melo, B. F., Guarino, M. P., et al. (2017b). Functional abolition of carotid body activity restores insulin action and glucose homeostasis in rats: key roles for visceral adipose tissue and the liver. Diabetologia 60, 158-168. doi: 10.1007/s00125-016-4133-y

Salman, S., Vollmer, C., McClelland, G. B., and Nurse, C. A. (2017). Characterization of ectonucleotidase expression in the rat carotid body: regulation by chronic hypoxia. Am. J. Physiol. Cell. Physiol. 313, C274-C284. doi: 10.1152/ajpcell.00328.2016

Schubert, P., Komp W., and Kreutzberg, G. W. (1979). Correlation of 5 nucleotidase activity and selective transneuronal transfer of adenosine in the hippocampus. Brain Res. 168, 419-424. doi: 10.1016/0006-8993(79)90186-0

Siński, M., Lewandowski, J., Przybylski, J., Bidiuk, J., Abramczyk, P., Ciarka, A., et al. (2012). Tonic activity of carotid body chemoreceptors contributes to the increased sympathetic drive in essential hypertension. Hypertens. Res. 35, 487-491. doi: 10.1038/hr.2011.209

Somers, V. K., Mark, A. L., and Abboud, F. M. (1988). Potentiation of sympathetic nerve responses to hypoxia in borderline hypertensive subjects. Hypertension 11, 608-612. doi: 10.1161/01.HYP.11.6.608

Soto, C. R., Ortiz, F. C., Vargas, R. V., Arroyo, J., and Alcayaga, J. (2010). Responses induced by acetylcholine and ATP in the rabbit petrosal ganglion. Respir. Physiol. Neurobiol. 172, 114-121. doi: 10.1016/j.resp.2010.05.003

Spergel, D., and Lahiri, S. (1993). Differential modulation by extracellular ATP of carotid chemosensory response. J. Appl. Physiol. 74, 3052-3056.

Starlinger, H. (1982). ATPases of the cat carotid body and of neighbouring ganglia. Z. Naturforsch. C 37, 532-539.

Tan, Z. Y., Lu, Y., Whiteis, C. A., Simms, A. E., Paton, J. F., and Chapleau, M. W., et al. (2010). Chemoreceptor hypersensitivity, sympathetic excitation, and overexpression of ASIC and TASK channels before the onset of hypertension in SHR. Circ. Res. 106, 536-545. doi: 10.1161/CIRCRESAHA.109.206946 
Teppema, L. J., and Dahan, A. (2010). The ventilatory response to hypoxia in mammals: mechanisms, measurement, and analysis. Physiol. Rev. 90, 675-754. doi: 10.1152/physrev.00012.2009

Torres, G. E., Egan, T. M., and Voigt, M. M. (1999). Hetero-oligomeric assembly of P2X receptor subunits. Specificities exist with regard to possible partners. J. Biol. Chem. 274, 6653-6659. doi: 10.1074/jbc.274.10.6653

Trussell, L. O., and Jackson, M. B. (1985). Adenosine-activated potassium conductance in cultured striatal neurons. Proc. Natl. Acad. Sci. U.S.A. 82, 4857-4861. doi: 10.1073/pnas.82.14.4857

Trzebski, A., Ta, M., Zoltowski, M., and Przybylski, J. (1982). Increased sensitivity of the arterial chemoreceptor drive in young men with mild hypertension. Cardiovasc. Res. 16, 163-172.

Tse, A., Yan, L., Lee, A. K., and Tse, F. W. (2012). Autocrine and paracrine actions of ATP in rat carotid body. Can. J. Physiol. Pharmacol. 90, 705-711. doi: 10.1139/y2012-054

Uematsu, T., Kozawa, O., Matsuno, H., Niwa, M., Yoshikoshi, H., Oh-uchi, M., et al. (2000). Pharmacokinetics and tolerability of intravenous infusion of adenosine (SUNY4001) in healthy volunteers. Br. J. Clin. Pharmacol. 50, 177-181. doi: 10.1046/j.1365-2125.2000.00214.x

van Dam, R. M., and Hu, F. B. (2005). Coffee consumption and risk of type 2 diabetes: a systematic review. JAMA 294, 97-104. doi: 10.1001/jama.294.1.97

Vandier, C., Conway, A. F., Landauer, R. C., and Kumar, P. (1999). Presynaptic action of adenosine on a 4-aminopyridine-sensitive current in the rat carotid body. J. Physiol. 515, 419-429. doi: 10.1111/j.1469-7793.1999.419ac.x

Varas, R., Alcayaga, J., and Iturriaga, R. (2003). ACh and ATP mediate excitatory transmission in cat carotid identified chemoreceptor units in vitro. Brain Res. 988, 154-163. doi: 10.1016/S0006-8993(03)03366-3

Verna, A., Talib, N., Roumy, M., and Pradet, A. (1990). Effects of metabolic inhibitors and hypoxia on the ATP, ADP and AMP content of the rabbit carotid body in vitro: the metabolic hypothesis in question. Neurosci. Lett. 116, 156-161. doi: 10.1016/0304-3940(90)90402-U

Vicario, I., Obeso, A., Rocher, A., López-Lopez, J. R., and González, C. (2000). Intracellular $\mathrm{Ca}(2+)$ stores in chemoreceptor cells of the rabbit carotid body: significance for chemoreception. Am. J. Physiol. Cell Physiol. 279, 51-61.

Wang, W. J., Cheng, G. F., Yoshizaki, K., Dinger, B., and Fidone, S. (1991). The role of cyclic AMP in chemoreception in the rabbit carotid body. Brain Res. 540, 96-104. doi: 10.1016/0006-8993(91)90495-H

Watt, A. H., Reid, P. G., Stephens, M. R., and Routledge, P. A. (1987). Adenosineinduced respiratory stimulation in man depends on site of infusion. Evidence for an action on the carotid body. Br. J. Clin. Pharmacol. 23, 486-490. doi: 10.1111/j.1365-2125.1987.tb03081.x

Watt, A. H., and Routledge, P. A. (1985). Adenosine stimulates respiration in man. Br. J. Pharmacol. 20, 503-506. doi: 10.1111/j.1365-2125.1985.tb05108.x

Wu, L. G., and Saggau, P. (1994). Adenosine inhibits evoked synaptic transmission primarily by reducing presynaptic calcium influx in area CA1 of hippocampus. Neuron 12, 1139-1148. doi: 10.1016/0896-6273(94)90321-2

$\mathrm{Xu}, \mathrm{F} ., \mathrm{Xu}, \mathrm{J} ., \mathrm{Tse}, \mathrm{F}$. W., and Tse, A. (2006). Adenosine stimulates depolarization and rise in cytoplasmic [Ca2+] in type I cells of rat carotid bodies. Am. J. Physiol. Cell Physiol. 290, 1592-1598. doi: 10.1152/ajpcell.00546.2005
Xu, J., Tse, F. W., and Tse, A. (2003). ATP triggers intracellular Ca2 + release in type II cells of the rat carotid body. J. Physiol. 549, 739-747. doi: 10.1113/jphysiol. 2003.039735

$\mathrm{Xu}, \mathrm{J} ., \mathrm{Xu}, \mathrm{F} ., \mathrm{Tse}, \mathrm{F} . \mathrm{W}$. , and Tse, A. (2005). ATP inhibits the hypoxia response in type I cells of rat carotid bodies. J. Neurochem. 92, 1419-1430. doi: 10.1111/j. 1471-4159.2004.02978.x

Yegutkin, G. G. (2008). Nucleotide- and nucleoside-converting ectoenzymes: important modulators of purinergic signalling cascade. Biochim. Biophys. Acta 1783, 673-694. doi: 10.1016/j.bbamcr.2008.01.024

Zapata, P. (2007). Is ATP a suitable co-transmitter in carotid body arterial chemoreceptors? Respir. Physiol. Neurobiol. 157, 106-115. doi: 10.1016/j.resp. 2007.01.002

Zhang, M., Piskuric, N. A., Vollmer, C., and Nurse, C. A. (2012). P2Y2 receptor activation opens pannexin-1 channels in rat carotid body type II cells: potential role in amplifying the neurotransmitter ATP. J. Physiol. 590, 4335-4350. doi: 10.1113/jphysiol.2012.236265

Zhang, M., Vollmer, C., and Nurse, C. A. (2017). Adenosine and dopamine oppositely modulate a hyperpolarization-activated current Ih in chemosensory neurons of the rat carotid body in co-culture. J. Physiol. doi: 10.1113/JP274743 [Epub ahead of print].

Zhang, M., Zhong, H., Vollmer, C., and Nurse, C. A. (2000). Co-release of ATP and ACh mediates hypoxic signalling at rat carotid body chemoreceptors J. Physiol. 525, 143-158. doi: 10.1111/j.1469-7793.2000.t01-100143.x

Zimmermann, H. (2016). Extracellular ATP and other nucleotides-ubiquitous triggers of intercellular messenger release. Purinergic Signal. 12, 25-57. doi: $10.1007 /$ s11302-015-9483-2

Zimmermann, H., Braun, N., Kegel, B., and Heine, P. (1998). New insights into molecular structure and function of ectonucleotidases in the nervous system. Neurochem. Int. 32, 421-425. doi: 10.1016/S0197-0186(97) 00126-5

Zimmermann, H., Mishra, S. K., Shukla, V., Langer, D., Gampe, K., Grimm, I., et al. (2007). Ecto-nucleotidases, molecular properties and functional impact. An. R. Acad. Nac. Farm. 73, 537-566.

Zoccal, D. B., Huidobro-Toro, J. P., and Machado, B. H. (2011). Chronic intermittent hypoxia augments sympatho-excitatory response to ATP but not to L-glutamate in the RVLM of rats. Auton. Neurosci. 165, 156-162. doi: 10.1016/j.autneu.2011.06.001

Conflict of Interest Statement: The authors declare that the research was conducted in the absence of any commercial or financial relationships that could be construed as a potential conflict of interest.

Copyright (c) 2017 Conde, Monteiro and Sacramento. This is an open-access article distributed under the terms of the Creative Commons Attribution License (CC BY). The use, distribution or reproduction in other forums is permitted, provided the original author(s) or licensor are credited and that the original publication in this journal is cited, in accordance with accepted academic practice. No use, distribution or reproduction is permitted which does not comply with these terms. 